\title{
Magia y metaficción en Promethea: Un cómic para conjurar el Apocalipsis.
}

\author{
Óscar García
}

Óscar García (Madrid, 1975) es licenciado en Teoría de la Literatura y Literatura Comparada por la Universidad Complutense, donde actualmente cursa su doctorado con una tesis sobre metaficción en la obra de Alan Moore. Ha publicado varios artículos en la revista digital Tebeosfera y ha coordinado el libro de ensayos Watchmen: Radiografías de una explosión. 


\title{
Resumen
}

Utilizando el concepto de metalepsis, tomado de la narratología literaria y trasladado al ámbito de la historieta, este artículo analiza la forma en que Alan Moore y J. H. Williams III construyen en Promethea un cómic que explícitamente busca expandirse más allá de la superficie de sus páginas. Pretendemos demostrar cómo en esta obra se hace posible romper la barrera entre realidad y ficción de dos modos muy concretos: mediante deixis (desde la ficción hacia su afuera) o con el empleo de proyecciones metafóricas (desde su exterior hacia la ficción). El despliegue de un amplio catálogo de este tipo de recursos metalépticos se pondría al servicio de una operación mágica que busca transmitir al lector la misma experiencia que viven los personajes del cómic: la gnosis, el contacto directo con lo inmaterial.

\begin{abstract}
Using the concept of metalepsis, taken from literary narratology and transferred to the comic medium, this article analyzes how Alan Moore and J. H. Williams III create in Promethea a comic that explicitly seeks to expand beyond the surface of its pages. We intend to demonstrate how in this work it is made possible the fracture of the barrier between reality and fiction in two very specific ways: through deixis (from fiction to its outside) or with the use of metaphorical projections (from its outside to fiction). The deployment of a huge amount of this type of metaleptic resources would serve a magical purpose that seeks to induce in the reader the same experience that the comic book characters are living: the direct contact with the immaterial known as gnosis.
\end{abstract}


El sincretismo como primer paso: Sophia o Shejiná o Imaginación o Promethea. La existencia estratificada, un estructuralismo místico. Apocalipsis como gnosis y gnosis como metalepsis.

La práctica del sincretismo no deja de resultar un ejercicio de simplificación: la asimilación de lo diverso en lo único, la transformación del nombre en sinónimo, la reducción de la diferencia entre lo múltiple al desplazamiento de lo semejante. Pero la red de correspondencias que funda y alimenta constituye la piedra angular de los sistemas mágicos que emergieron en la Inglaterra de finales del siglo xIx y principios del xx. Y esos sistemas mágicos son el sustrato del que nace la obra que vamos a comentar. Promethea, el cómic creado por Alan Moore y J. H. Williams III, adquiere sentido dentro de esa misma tradición de esoterismo anglosajón que se podría remontar al pensamiento del mago renacentista John Dee y de la que resultarían continuadores los miembros de la Orden Hermética del Amanecer Dorado ${ }^{1}$ y figuras posteriores como Aleister Crowley, Austin Osman Spare o Kenneth Grant. El vínculo legitima las palabras de esta introducción y aligera en ellas el juicio de la mirada rigurosa. Permite aproximarlas a lo literario - a la trama, al relato coherente sea verídico o no- y diferir durante unos párrafos más la perspectiva crítica. Toleremos entonces ese desliz, dejémonos llevar por el ímpetu de la connotación y sus conexiones simbólicas y hablemos de un autor de cómic, de los gnósticos cristianos y de los místicos judíos, como si todos ellos hablaran de lo mismo.

Durante los primeros siglos que sucedieron a la aparición del cristianismo, antes de que llegara a imponerse el dogma de la Iglesia romana, surgieron en el norte de África y en Asia Menor una multitud de sectas, cultos y escuelas que se agruparon posteriormente bajo la denominación de "gnósticas". Pese a las inevitables diferencias entre ellas, todas compartían una idea similar del conocimiento de Dios, de la "gnosis", que aludía a un contacto sobrenatural, a un acceso a otro plano superior de existencia. Esa experiencia provocaría una transformación psíquica en aquellos que la consumaran, haciéndose partícipes de la esencia divina. ${ }^{2}$ Es en ese ambiente, en la Alejandría del siglo v d. C., donde Alan Moore sitúa el origen de Promethea, una niña hija de un gnóstico que, tras el asesinato de su padre a manos de un grupo de seguidores de la Iglesia católica, huye al desierto. Allí será convertida en una historia viva por el dios doble Thoth-Hermes que le ofrecerá refugio en la Inmateria. En el reino de la Imaginación, de las ficciones, en el plano divino al que solo tienen acceso los iniciados, en el mundo platónico de las ideas, en el comienzo del sendero 32 del árbol sefirótico, en ese no lugar sincrético, en la más extensa de todas las heterotopías.

En el sistema adoptado por la secta gnóstica de los Valentinianos, que alcanzó un importante grado de difusión a partir del segundo siglo después de Cristo, destaca como

\footnotetext{
${ }^{1}$ En la Orden Hermética del Amanecer Dorado, fundada por William Robert Woodman, William Wynn Westcott y Samuel Liddel MacGregor Mathers, se articuló uno de los primeros sistemas sincréticos de la modernidad incorporando ideas procedentes del hermetismo neoplatónico, las corrientes cabalísticas medievales y posteriores, el Tarot, la astrología, las enseñanzas de los Vedas... Dos de sus miembros, Westcott y McGregor Mathers, son responsables de la traducción al inglés de textos fundamentales de todas esas corrientes de pensamiento que buscaban sintetizar en una misma vía. Entre los libros que tradujeron se encuentran el Sefer Yetzirah o Libro de la Creación, uno de los textos más antiguos del misticismo judío; el Zóbar, obra fundamental de las corrientes cabalísticas medievales; o la Clavicula de Salomón, un célebre grimorio renacentista dedicado a la invocación de demonios. También reeditaron otras obras ya traducidas al inglés como el Poimandres, pieza incluida en ese Corpus Hermeticum, relacionado con el gnosticismo alejandrino, que fue rescatado junto a las obras de Platón de las bibliotecas de Bizancio antes de su caída.

${ }^{2}$ Jonas, H. The Gnostic Religion. Boston, Beacon Press, 1958, pp. 34-35.
} 
elemento fundamental la figura simbólica de Sophia. Para los seguidores de Valentín la totalidad del reino divino queda representada en el Pleroma, una estructura en forma de árbol sustentada sobre quince eones, entidades compuestas por un principio masculino y otro femenino, que van emanando progresivamente de la unión primordial entre el Abismo (Bythos) y el pensamiento (Ennoia). De ese primer eón nace el siguiente que une la Mente (Nous) y la Verdad (Alêtheia), y de este surgirá el formado por la Palabra (Logos) y la Vida (Zoê). Así continuaría el proceso de emanación hasta llegar a un último eón que suma la Voluntad (Thelêtos) y la Sabiduría (Sophia). En el relato cosmogónico de los Valentinianos solo el Nous, por su lugar en el Pleroma, podía deleitarse en la contemplación del eón perfecto, origen de todo lo creado. Pero Sophia deseosa también de comprender la grandeza del primer eón rompió su unión y penetró en el Abismo, en Bythos, provocando una inestabilidad inaceptable que afectó a toda la existencia. Solo gracias al poder que consolida la totalidad, el poder del Límite (Horos), Sophia vio restituido su lugar en el último eón. Pero pese a que la integridad del Pleroma se vio restaurada, la Intención y la Pasión de Sophia se separaron de ella dando origen a una entidad diferente. Una Sophia inferior, exiliada sin posibilidad de retorno, que se convertiría en madre del Demiurgo, creador del plano material de la existencia, y descendería sobre el hombre como pneuma, su componente más elevado que le conecta con lo divino - el ser humano estaría formado de materia, alma y espíritu o pneuma-. Ese elemento pneumático, simbolizado por la Sophia inferior, consumaría la gnosis al recibir y unirse al Logos, la Palabra, restituyendo de nuevo la perfección que permitiría su retorno al Pleroma, donde la fractura original entre lo espiritual y lo material quedaría por fin reparada. ${ }^{3} \mathrm{Y}$ así es como llegaría el fin del mundo, un Apocalipsis que, entendido desde una perspectiva terrenal podría interpretarse como una gnosis multitudinaria, una experiencia mística compartida y global: todo ser humano accediendo simultáneamente a ese plano existencial de lo divino. Así parece creerlo Alan Moore, así lo refleja en Promethea.

Se puede continuar el avance por esa red de correspondencias explorando una obra dedicada a Walter Benjamin por su amigo Gershom Scholem, uno de los más prestigiosos investigadores en el ámbito de la tradición mística judía. ${ }^{4}$ En ella, refiriéndose al Zóhar, la obra más representativa de la Cábala medieval donde confluyen y se perfeccionan las doctrinas místicas precedentes, Scholem comenta las diferentes formas de representar el simbolismo de la emanación creadora. La más reconocible es la doctrina del Árbol de la vida. El relato que la recoge narra cómo a partir de En Sof, el aspecto incognoscible de la divinidad —el Infinito, la Nada-, van emanando sucesivamente las sefirot, los atributos por los que se revela al hombre: primero Kéter, luego el par de Hojmá y Biná, diferenciadas y contrapuestas como poderes masculino y femenino respectivamente; después Hésed y Din, también en mutua oposición pero dando lugar a Tiferet gracias a su conjunción; tras ella Netsaj y Hod, otro par complementario que confluye en Yesod; y por último Maljut, que delimita la frontera con el mundo material. La analogía permite estrechar lazos entre Pleroma gnóstico y Árbol de la vida, entre eones hermafroditas y pares de sefirot. Ambos sistemas poseen una naturaleza múltiple: construyen un relato de la creación y a la vez cartografían un mapa de la existencia, a escala macroscópica y microscópica, en todo el universo y en un solo ser humano.

\footnotetext{
3 Jonas, H. Op. cit. pp. 179-197.

${ }^{4}$ Scholem, G. Las grandes tendencias de la mística judía. Madrid, Siruela, 1996.
} 
Esa condición topológica del Árbol de la vida se metaforiza en varias ocasiones en Promethea. En una de ellas aparece representado como el diagrama que se traza con tiza en el suelo para jugar a la rayuela, de modo que los saltos entre casillas servirían para representar el tránsito entre sefirot. En otra asume el diseño propio de un plano de metro donde cada sefirá correspondería a una estación.
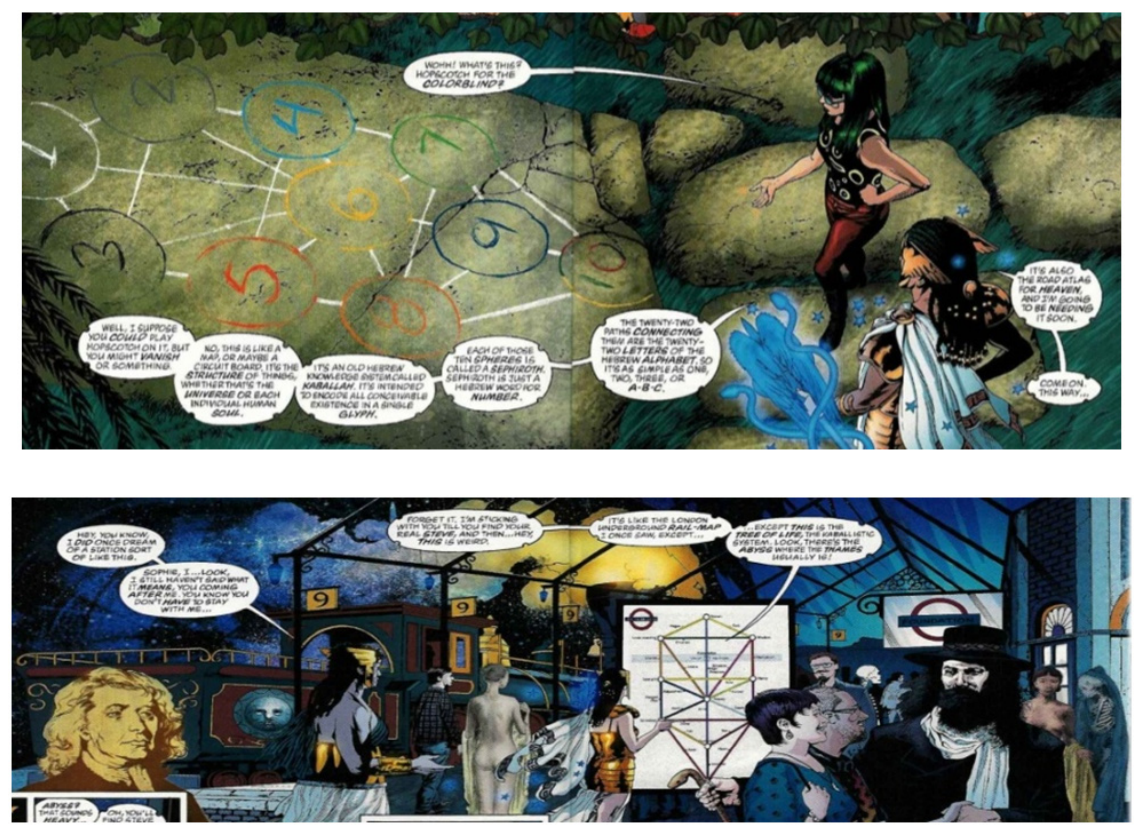

FIG. 1. (Arriba) Viñeta de las páginas 8-9 del n. ${ }^{\circ} 13$ de Promethea (abril 2001). (Abajo) Viñeta de las páginas 20-21 del n.o 14 de Promethea (junio 2001).

Durante los números 12 al 23 de la serie, Promethea, guiándose por esos mapas, emprende el mismo viaje ascendente en busca de lo divino que recorrió la Sophia de los gnósticos. La coartada inicial en cierto modo es la misma. El deseo que impulsa la búsqueda de PMT / Barbara Shelley en pos de su difunto marido, el autor de cómic Steven Shelley, representa la misma necesidad de fundir lo femenino y lo masculino, de restituir la fractura original. El resultado final de la aventura también es el mismo: la contemplación directa de Dios. Asciende Promethea por el árbol sefirótico hasta Kéter y cuando culmina ese viaje desciende por fin como Sophia transformada, iluminada — como indica el ojo dentro del triángulo que aparece sobre su frente-, preparada para desatar el apocalipsis, para llevar la revelación gnóstica a todos los seres humanos. Así lo relata en Biná la encarnación femenina de lo divino, identificada con la Shejiná y representada en el cómic como la superposición de la Virgen María y la ramera Babalón (FIG. 2).

Con la mención a la Shejiná se va cerrando el círculo que pretendía trazar esta introducción para ir cercando al personaje de Promethea y hacerle próximo, para intuir lo que significa como símbolo y permitir teorizar sobre las intenciones de Moore al convertirla en protagonista de un cómic extraordinariamente atípico. La idea que representa la Shejiná, como elemento femenino de la divinidad, resulta fundamental para sustentar el dualismo creativo sobre el que se construye la Cábala medieval. En palabras de Gershom Scholem:

\footnotetext{
5 Cuando hagamos referencia a las distintas encarnaciones que asume Promethea utilizaremos la fórmula: $\mathrm{PMT} /$ personaje en que se manifiesta.
} 

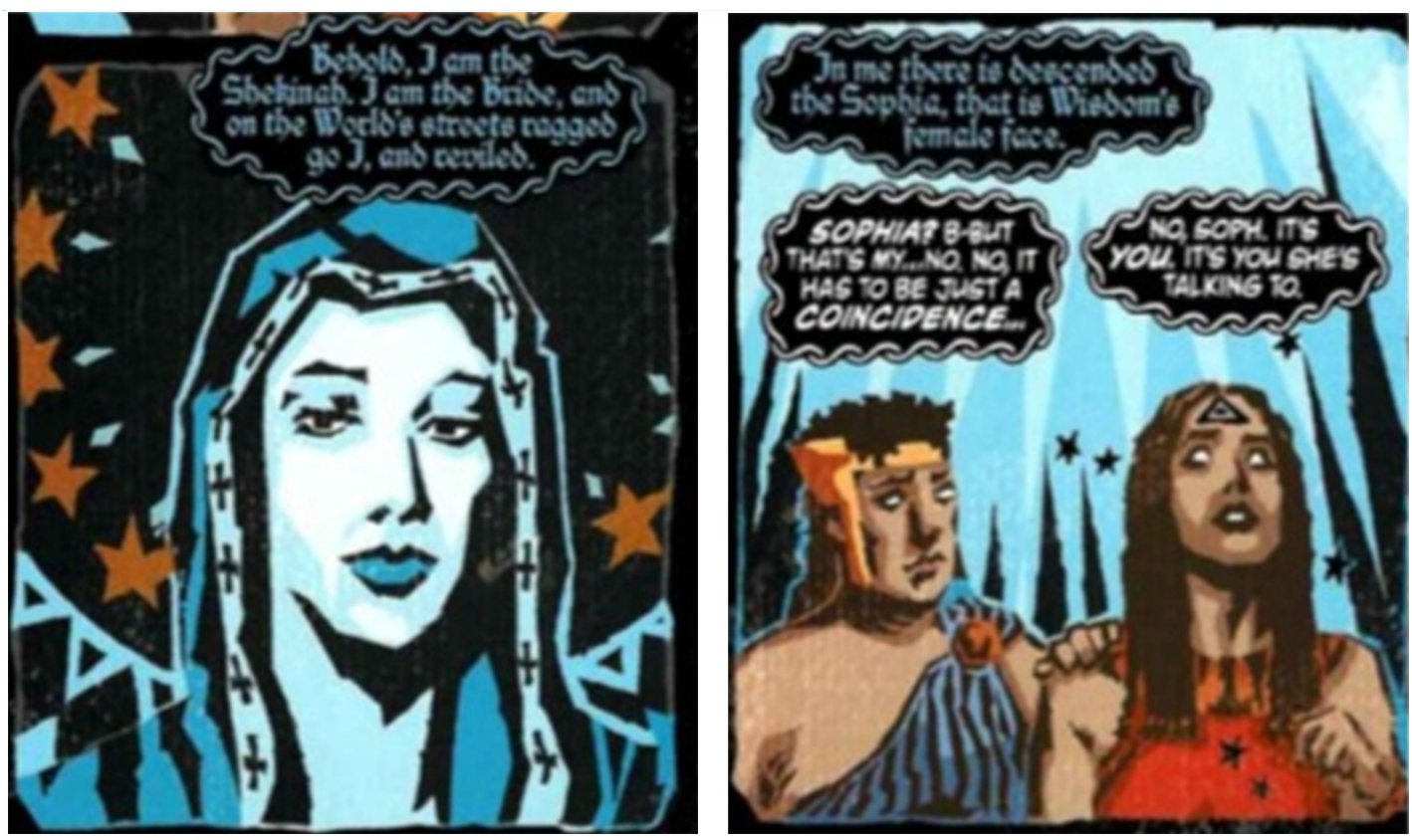

FIG. 2. (Izquierda) Viñetas de la página 19 del n.o 21 de Promethea (agosto 2002).

"La unión de Dios con la Shejiná constituye la verdadera unidad de Dios", 6 la divinidad no es absoluta, establece una unión de dos mitades, una masculina y otra femenina. Según recoge el Zóhar, en los orígenes de la existencia esa unidad era estable y el ser humano, todavía una criatura puramente espiritual, se relacionaba directamente con Dios. Pero el pecado rompió el vínculo y otorgó al andrógino primordial su condición corpórea, afectando a la unidad divina y a toda la creación que sustentaba. ${ }^{7}$ Produciendo una fractura entre lo masculino y lo femenino: el exilio de la Shejiná. La redención, la restauración de esa armonía, es la misión del hombre en este mundo que intenta expresar la palabra "ticún" empleada por cabalistas posteriores. Cuando se restituya esa unión primigenia, de la que surge toda creación, el mundo material dejará de existir como lo conocemos.

Tanto la Sophia de los gnósticos como la Shejiná de los místicos judíos comparten un mismo carácter liminal, son criatura y frontera. Ambas definen en sí mismas el límite entre el mundo divino y el mundo material, abren el pasadizo entre esos dos planos de la existencia y sirven de portal entre ellos. En sus respectivos sistemas simbólicos representan el ímpetu del salto metafísico, un movimiento transgresor que instala la porosidad en ciertos muros donde la lógica la prohíbe. Un gesto que trasladado al ámbito del estudio de la ficción equivaldría a lo que la narratología ha definido como metalepsis.

Y aquí, cuando el sincretismo de la simbología teosófica amenaza con contagiar la esfera de la teoría narrativa, debemos detenernos temporalmente. Dar fin al juego propuesto en esta introducción superponiendo muchos nombres en uno para componer un relato que ha tomado ya muchas formas distintas pero similares: la historia del fin del mundo - el

\footnotetext{
${ }^{6}$ Scholem, G. Op. cit. pp. 255-257.

7 El mito de la creación del hombre que recoge el Génesis, en la versión latina adoptada por el catolicismo, parece apenas un remake de serie B de este relato. El hermafrodita original que se parte en dos mitades similares se ve sustituido por un hombre al que extraen una costilla para clonar una mujer. Pecado original y criminalización de lo femenino: christianxploitation en pleno siglo iII d. C. En el discurso de Aristófanes sobre el amor que aparece en El banquete de Platón resuenan ecos de este mismo relato.
} 
Apocalipsis según Moore, podríamos llamarlo ahora- desencadenado por Promethea (o Sophia o la Imaginación o la Shejiná), encarnación del poder creador, (o pneuma, resto divino en lo humano, principio activo de lo femenino arquetípico) al emprender la aventura que culmina con la restauración de la fractura cósmica original (o de la caída o del primer pecado); al consumar de nuevo la unidad de la existencia conectando el plano material con el espiritual; al llevar la gnosis a todos y cada uno de los seres humanos. Dentro y fuera del cómic. A quien lo habita y a quien lo lee. Tomando el apocalipsis como gnosis y la gnosis como metalepsis. Literalizando el nombre de la protagonista del cómic: Sophie Bangs. Hacia el Big Bang de Sophia y más allá.

Todos los detalles a continuación.

\section{Léxico fundamental para la interpretación de grimorios: interludio dedicado a la teo- ría narrativa. Beta-testing la metalepsis (a nivel discursivo).}

Las operaciones mágicas requieren la intervención de palabras exactas. Para provocar la aparición de un demonio o hacer desaparecer un conejo en una chistera se debe pronunciar fonema a fonema, sin equívoco ni desviación, el conjuro correspondiente. Las teorías científicas también requieren el concurso de términos precisos con definiciones acotadas y para entender ese grimorio autoejecutable que es Promethea antes resulta necesario dedicar cierto espacio a considerar uno de ellos en concreto: "metalepsis".

Al comenzar a referir el concepto se impone obligatoriamente la glosa de las palabras que le dedicó Gerard Genette cuando retomó esa figura propia de la retórica clásica y la trasladó al ámbito de la teoría narrativa. ${ }^{8}$ Genette definiría la metalepsis como una transgresión entre niveles narrativos diferenciados. Una intromisión que franquearía contra toda lógica "una frontera movediza pero sagrada entre dos mundos: aquel en que se cuenta, aquel del que se cuenta", ${ }^{9}$ que equivaldría a un imposible salto a la comba (-lepsis) entre un mundo "real" y un mundo "ficcional" (-meta). ${ }^{10}$ Aquí se intuyen ya ciertos paralelismos formales con la gnosis, con ese ascenso místico entre un mundo "material" y otro "espiritual", que convertirán a esta figura en la metáfora mística perfecta.

En esa primera aproximación se apunta ya un parámetro clave para su análisis: la dirección que toma la transgresión. La metalepsis puede darse del mundo "real" al "ficcional" o a la inversa: un narrador puede entrometerse en la vida de sus personajes o un personaje puede llegar a conocer a su autor. Genette abre también la discusión sobre otro aspecto fundamental: los efectos que produce sobre el lector. Entre ellos destaca la incomodidad,

\footnotetext{
${ }^{8}$ Genette propuso su teoría sobre la metalepsis, inicialmente y de forma muy breve, en su Discurso del relato, texto incluido en la obra Figuras III. Posteriormente la ha ido ampliando en obras sucesivas, tratándola más extensamente en: Genette, G. Nuevo discurso del relato. Madrid, Cátedra, 1998 [1993]. Y en: GenetTe, G. Metalepsis. De la figura a la ficción. Buenos Aires, Fondo de Cultura Económica, 2004 [2004].

9 Genette, G. Figuras III. Barcelona, Lumen, 1989 [1972], p. 291.

10 Aludir así a un mundo "real" opuesto a un mundo "ficcional" resulta, en cierto modo, simplificador pero conveniente como primera aproximación al fenómeno. Este mundo "real" podría o no identificarse con el plano extraficcional que habitan lector y autores porque, al fin y al cabo, la realidad es solo el lugar que habita quien la nombra y se sitúa en el plano narrativo desde el que es nombrada: para Sophie Bangs la realidad es lo que para nosotros es un mundo encerrado entre viñetas.
} 
el desconcierto incubado por la sugerencia de una hipótesis inaceptable: la de existir atrapado en una infinita recurrencia de ficciones concéntricas. ${ }^{11}$

Asociada irremisiblemente a la metaficción, la metalepsis ha ido acaparando interés crítico y se le han dedicado numerosos estudios. No es el objetivo de este texto citar todos ellos $\mathrm{y}$, aunque haremos referencia a algunos, nuestra intención principal es afrontar su consideración desde una perspectiva transmedial, problematizando la traslación a la historieta de una categoría definida inicialmente para textos literarios.

Una de las figuras más activas en el campo de la narratalogía transmedial aplicada al cómic, Karin Kukkonen, ha analizado en varios artículos cómo se produce en él la metalepsis. Kukkonen considera que las situaciones enmarcadas dentro de las viñetas representarían acontecimientos del mundo "ficcional" mientras que el mundo "real" emergería del espacio entre viñetas, de la calle, y se expandiría hacia fuera, más allá de la superficie de la página, al territorio que habitan su autor y sus lectores. La transgresión del marco de la viñeta constituiría así, según ella, la forma más pura de metalepsis ligada al modo de representación propio del cómic. ${ }^{12}$ Pero Kukkonen propone una definición mucho más amplia y comprensiva, tomando como punto de partida el análisis que Thierry Groensteen dedica a la autorreflexividad en el cómic. Groensteen entiende que el código de la historieta está compuesto por el material gráfico del medio, su modo específico de representación, su proceso de producción y las instituciones sociales que le rodean. ${ }^{13}$ Cuando esas convenciones representativas, que normalmente pasan desapercibidas al lector, adquieren preeminencia, destapando los mecanismos que intervienen en el proceso de producción y colocándolos en primer plano, nos encontramos frente a un fenómeno de autorreflexividad. Si además, en esa exposición de las sutilezas propias de la técnica artística, se transgrede alguna de las relaciones estándar entre componentes semióticos y su forma de intervenir en el contexto productivo, identificaríamos entonces la presencia de una metalepsis. De este modo, la invasión de la calle que conlleva la ruptura de la viñeta no constituiría la única transgresión metaléptica posible en el medio, pudiendo detectarse situaciones similares en el estilo del dibujo o en la interacción de caracteres con elementos paratextuales, por mencionar otros ejemplos.

Kukkonen adapta las teorías de Genette para redefinir la metalepsis en términos de producción en lugar de en términos de narración. Así, el mundo en que se cuenta - mundo "real" - pasa a ser entendido como contexto de producción y recepción mientras que el mundo contado - mundo "ficcional" - pasa a convertirse en producto. La transgresión entre ambos que daba lugar a la metalepsis en el medio literario se replantea entonces como una interacción de los elementos del mundo ficcional del cómic con los elementos de ese contexto de producción y recepción, equivalente al mundo "real", donde además de autor y lector se incluirían también las convenciones de representación. ${ }^{14}$

Respecto a la dirección que puede tomar la transgresión metaléptica, ofrece también un matiz imprescindible para complementar su propuesta. Incorporando una perspectiva

\footnotetext{
11 Genette, G. (1980). Op. cit. p. 236.

12 Kunkonen, K. "Metalepsis in Comics and Graphic Novels", en Kukronen, K. y Kuimek, S. (eds.).

Metalepsis in Popular Culture. Berlín, De Gruyter, 2011, pp. 215-217.

13 Groensteen. T. en Kukronen, K. Op. cit. p. 215.

14 KukKonen, K. Op. cit. pp. 219-222.
} 
funcionalista, Kukkonen considera que cuando los personajes asumen roles propios de un estado previo en el contexto de producción o posterior en el de recepción - personajes que se dibujan a sí mismos como si fueran sus propios autores o que dan la vuelta a una página como harían sus lectores - nos encontraremos frente a una metalepsis ascendente. De forma inversa, cuando las funciones del autor se hacen presentes en el mundo ficcional - modificando el estilo con el que están dibujados los personajes, abocetándolos, etc. - trataríamos con una metalepsis descendente. ${ }^{15}$

Sin embargo, creemos que Kukkonen no acierta en el mismo grado cuando intenta trasladar al medio la tipología propuesta por Marie Laure Ryan ${ }^{16}$ que distingue entre metalepsis retóricas y ontológicas del siguiente modo: en las primeras tendría lugar una transgresión de la frontera entre niveles narrativos de carácter meramente ilocutivo, mientras que en las segundas se produciría una fractura material de la misma que permitiría el tránsito de entidades entre esos planos diferenciados.

En primer lugar nos parece desafortunado que señale su diferencia a partir de un criterio aplicable únicamente a un caso particular de metalepsis: la invasión física de la calle. Un personaje, al traspasar esa barrera, ejecutaría una metalepsis ontológica. Pero dirigirse al lector, como hace Animal Man en una conocida página de la serie guionizada por Grant Morrison (FIG. 3), lo interpreta como una metalepsis retórica, ya que la transgresión en este caso no es material, posee solo carácter ilocutivo y deíctico: el empleo de un "tú" en el diálogo del personaje y de una mirada directa en el plano icónico de la imagen. Es obligatorio notar que este es el único ejemplo de metalepsis retórica que propone Kukkonen y a nuestro parecer no solo no resulta acertado, tampoco hemos encontrado otro distinto.
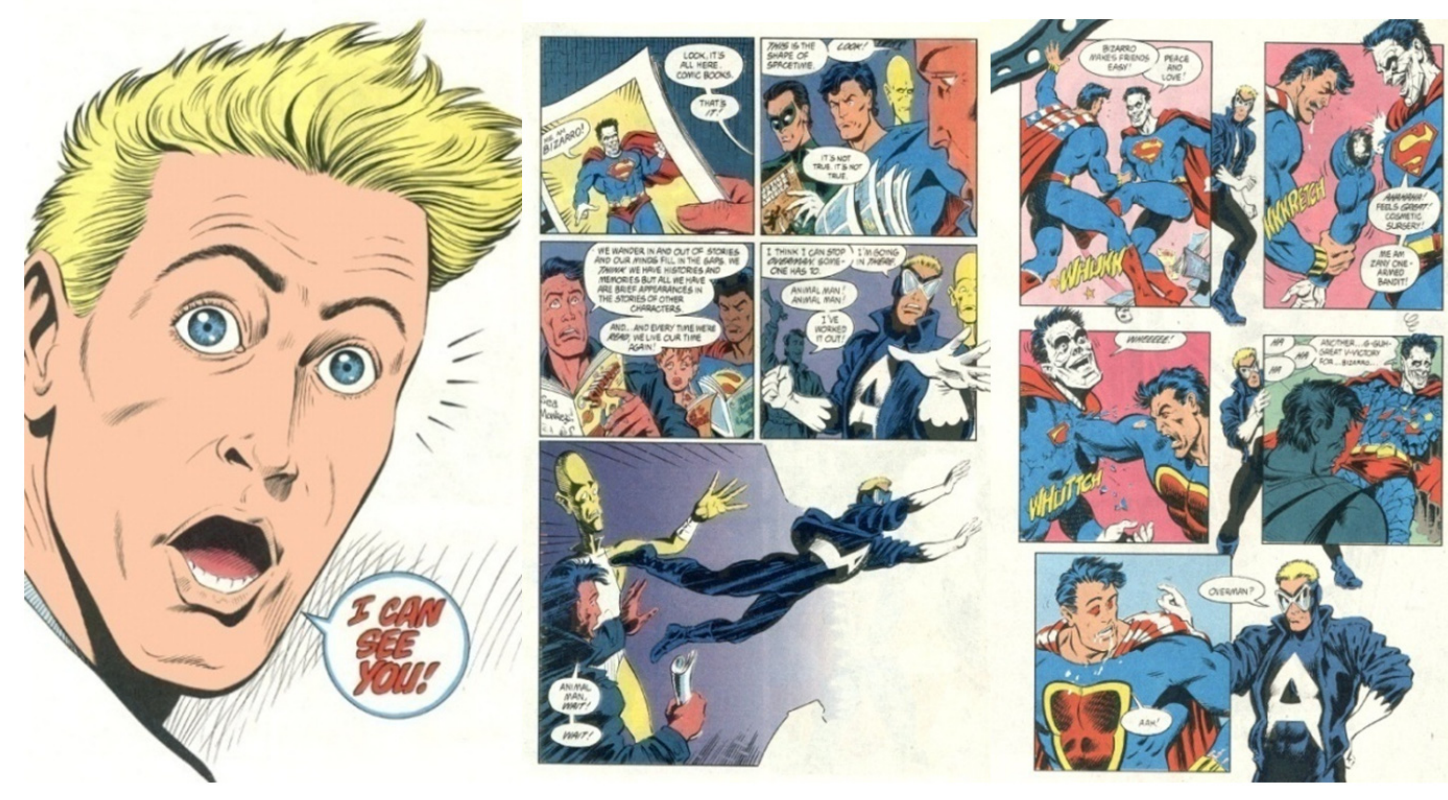

FIG. 3. Páginas de Animal Man empleadas por Karin Kukkonen para ejemplificar su tipología de metalepsis. (Izquierda) Metalepsis retórica: página 11 del n. ${ }^{\circ} 19$ (enero 1990). (Centro y derecha) Metalepsis ontológica: páginas 8 y 9 del n. ${ }^{\circ} 24$ (junio 1990).

${ }_{15}$ Ibid.p. 224.

16 Ryan, M. L. Avatars of Story. Minneapolis, University of Minnesota, 2006, pp. 204-206. 
Se podría argumentar en contra de esa definición que la ontología de la calle no es similar a la de la superficie externa al cómic, aunque ambas sean identificados con el mundo "real" por Kukkonen, y que la apelación del personaje al lector externo, con su palabra y su mirada, resulta mucho más transgresora, ontológicamente hablando, que verle darse un paseo por los espacios en blanco de la página. Esa deixis sí es capaz de atravesar la frontera de la ficción y llegar el mundo "real" - seguramente ese sea el único modo de conseguirlo- mientras que con la invasión de la calle solo se alcanza una zona intermedia, un espacio híbrido que metaforiza el mundo "real", que no es viñeta pero tampoco comparte las propiedades ontológicas de la exterioridad del cómic. Una región que ubicada en la topografía del medio correspondería al espacio reservado al discurso.

Para intentar ampliar ese criterio inicial, que ya de por sí creemos inadecuado, y poder incluir todos las casos de metalepsis que deja fuera si se considera como único factor de discriminación, Kukkonen recurre de nuevo a la perspectiva funcionalista y argumenta que existe un "subconjunto" de metalepsis ontológicas en las que no se producen transgresiones físicas aunque sí se asumen roles ontológicamente diferentes a los convencionales. ${ }^{17}$ Una instancia de este tipo particular de metalepsis se produciría cuando un personaje levanta simuladamente la esquina de una página, algo que solo el lector puede hacer. Con este añadido a la definición inicial se rompe la univocidad y elegancia que debería poseer la descripción de cualquier categoría. G. 4. Esquema de la comunicación nwarrativa literaria (izquierda) y en el medio del cómic (derecha).

Consideramos que en el medio del cómic se impone la renuncia a esa clasificación y la necesidad de reformular otra, fundada sobre criterios mejor adaptados a sus propiedades semióticas, muy distintas a las de la narración literaria. Presentaremos aquí una propuesta alternativa tomando como punto de partida la traslación del esquema de comunicación narrativa considerado en literatura y adaptándolo a las particularidades de la historieta.

Como se puede apreciar a partir de la figura 4, ambos sistemas narrativos comparten una estructura similar en la que se detecta un primer nivel externo a la obra, denominado realidad extraficcional, donde se encontrarían sus productores y consumidores. En ese plano estaría contenida la ficción, la obra en sí misma, y en ella a su vez se distinguirían dos estratos: el nivel del discurso y el nivel de la acción.

El nivel del discurso equivaldría a la epidermis de la obra, a la superficie material sobre la que se organizan los diferentes elementos del código o códigos del medio para dar forma a un mensaje concreto, a un texto narrativo. Es en este estrato donde se manifiestan las diferencias entre medios. En el caso de la literatura se localizan en él dos entidades o categorías narratológicas: el narrador, que actúa como emisor del relato, y su complemento necesario, el narratario, que lo recibe en ese nivel discursivo vedado ontológicamente al lector extraficcional. El producto de su interacción es un mensaje codificado únicamente a partir de lenguaje verbal en el que se puede identificar inequívocamente una voz, la del narrador. Pero las categorías de narrador y narratario exportadas a medios multimodales, donde se combinan varios códigos semióticos, resultan problemáticas. Renunciar a su aplicación puede convenir en mayor medida que intentar implantarlas por la fuerza. Creemos que ese es el caso del cómic, poseedor de una gramática basada en la suma de lo visual y lo verbal, que no permite identificar claramente esa voz unívoca del narrador literario, asociada a lo puramente verbal. Considerar su existencia como figura organizadora

\footnotetext{
${ }^{17}$ KukKonen, K. Op. cit. p. 223.
} 

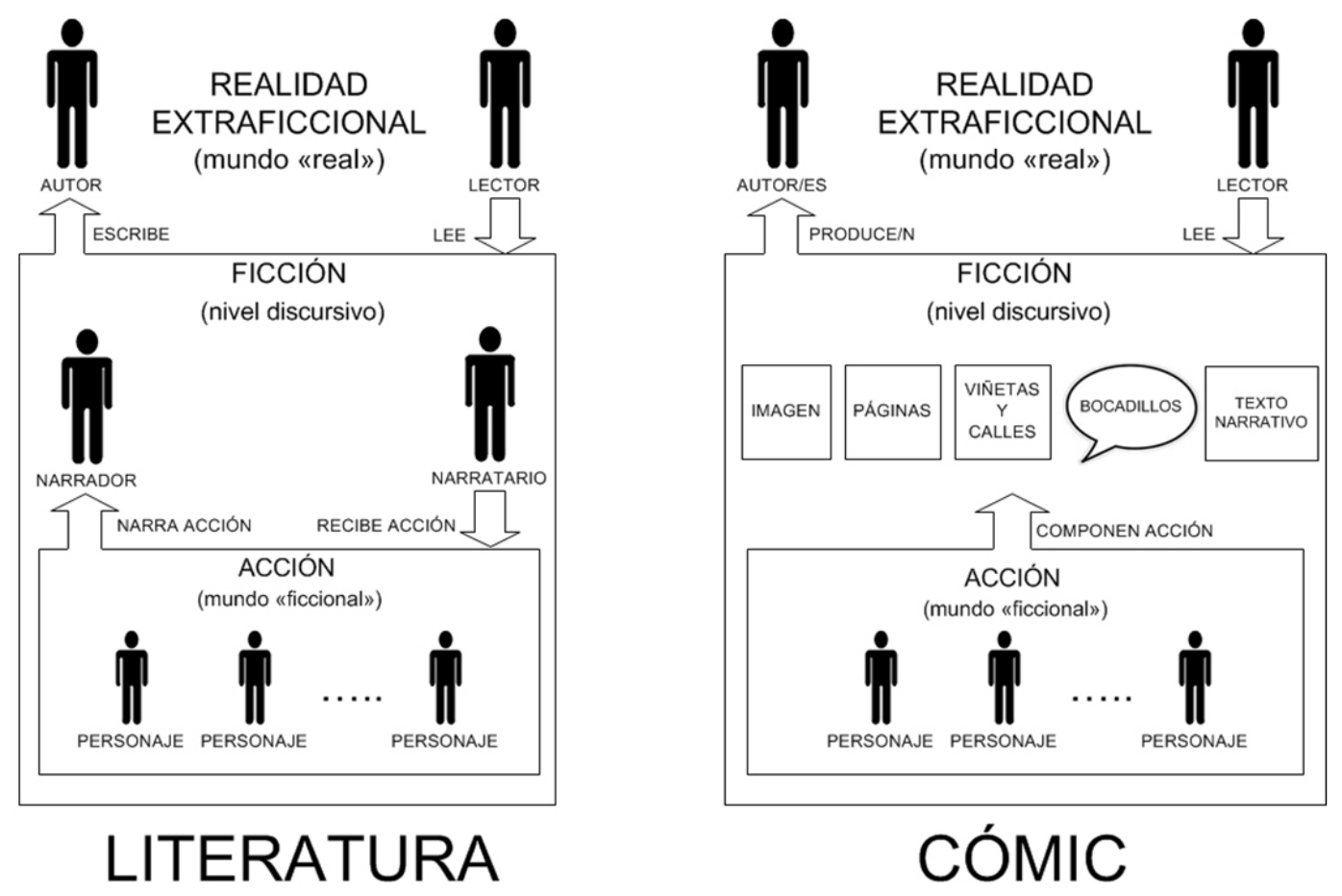

FIG. 4. Esquema de la comunicación narrativa literaria (izquierda) y en el medio del cómic (derecha). ${ }^{18}$

del discurso multimodal del cómic derivaría en un ejercicio de reduccionismo preferiblemente descartable. Sin entrar en el análisis que merece esta cuestión, prescindiremos de narrador y narratario, descartando el empleo de este tipo de mediadores en la historieta.

Por otro lado, inextricablemente unido al plano del discurso - emanando de él como un eón o una sefirá, erigiendo una estructura que comparte similitudes con Pleroma y Árbol de la vida - se despliega el nivel de la acción, de los sucesos acaecidos a los personajes en el mundo ficcional que genera el texto. Este estrato es el que resulta trasferible de un medio a otro y es objeto potencial de cualquier adaptación empleando un discurso narrativo diferente. En esos tránsitos, el nivel de la acción no debería variar sustancialmente, solo mudaría su piel. Por eso, podría llegar a pensarse como núcleo de cualquier sistema narrativo y reducto de su esencia, de esa narratividad fruto del destilado de mayor pureza en un relato.

A partir del esquema propuesto podemos definir una tipología alternativa a la clasificación que diferencia metalepsis retóricas y ontológicas. Además de la inconsistencia que conlleva su definición, también la denominación empleada resulta imprecisa para caracterizar las peculiaridades que distinguen unas metalepsis de otras en nuestro medio. Se podría considerar que la metalepsis en cómic puede poseer simultáneamente y en distinto grado una componente ontológica —algo de transgresión material, de intromisión en planos de existencia lógicamente aislados- y una componente retórica -otra parte de operación a nivel de discurso, de transgresión en el manejo de los códigos del

\footnotetext{
${ }_{18}$ Todos los esquemas que aparecen en este artículo son de elaboración propia.
} 
medio- La presencia de imagen icónica en la historieta, con la materialidad intrínseca que conlleva este tipo de signo, y su sintaxis basada en el empleo de marcos sólidos que se pueden fracturar de forma visible, como la página y la viñeta, impone en casi todos los casos una componente ontológica a cualquier transgresión metaléptica. Algo que no sucede en literatura, donde el grado de abstracción que conlleva el signo lingüístico, la falta de carnalidad de lo verbal, permite obviar esa materialidad en muchas instancias del fenómeno. Por eso, siguiendo la propuesta de Dorrit Cohn ${ }^{19}$ parece preferible establecer como criterio para nuestra tipología el nivel narrativo sobre el que se produce la interferencia propia de la metalepsis y distinguir entre discursivas y ficcionales.

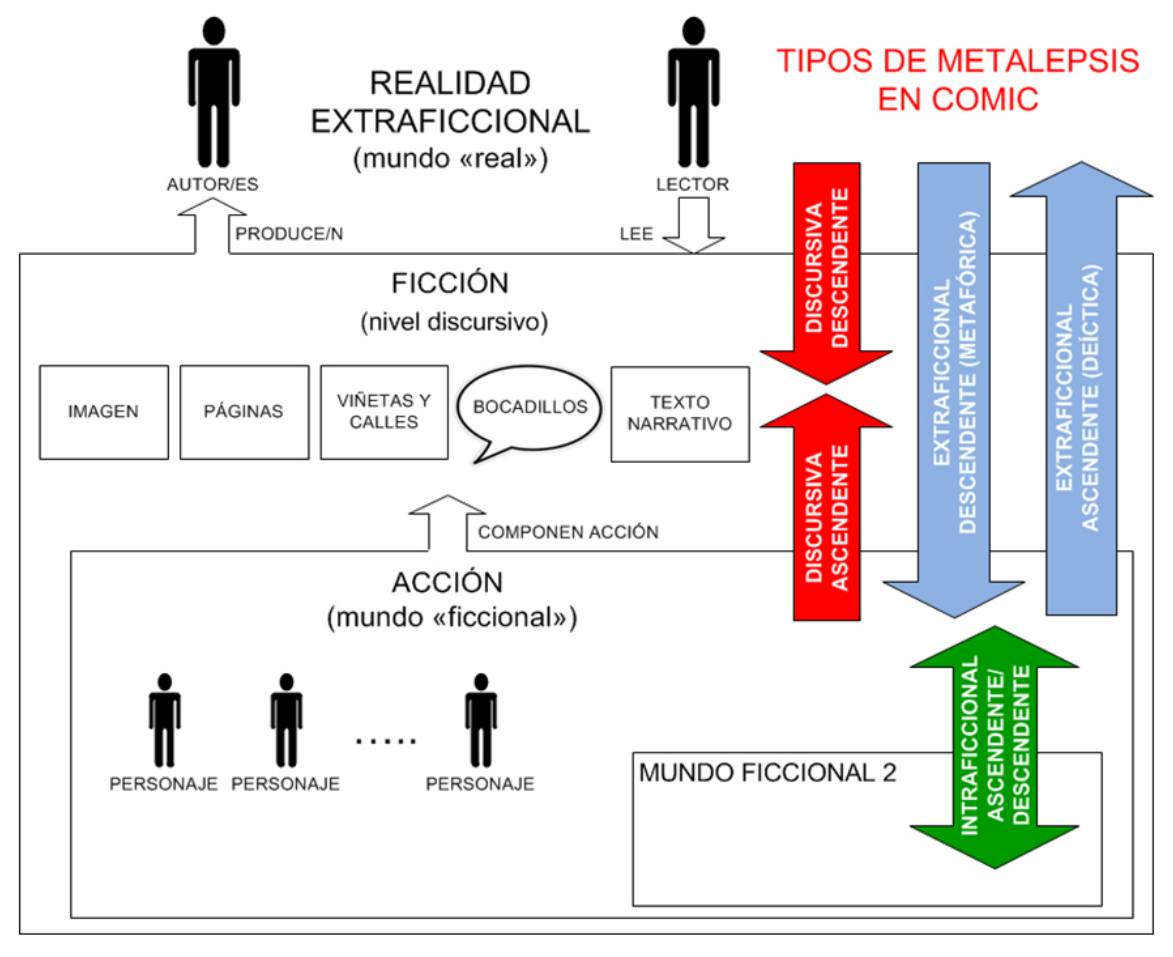

FIG. 5. Tipos de metalepsis en el medio del cómic.

En las metalepsis discursivas la contaminación paradójica afecta al nivel del discurso y por tanto poseerán una componente retórica muy significativa. En los ejemplos utilizados por Kukkonen, encontraríamos un caso de este tipo cuando Animal Man sale de la viñeta invadiendo la calle. Pero como acabamos de comentar, en esa metalepsis se detecta también una fuerte componente ontológica, patente en la ruptura material del marco de la viñeta y en la transgresión física que perpetra el personaje.

Es posible también que se produzcan interferencias entre el nivel ficcional primario y el mundo "real" dando lugar a metalepsis extraficcionales. Pero para que eso suceda deben darse en unas circunstancias muy particulares. Una de ellas requeriría el concurso de una proyección descendente de entidades "reales", ficcionalizándolas para introducirlas en el nivel de la acción. La representación ficticia de un autor dentro de su obra sería un ejemplo de este tipo. En otro caso, ejemplificado en esa página donde Animal Man mira directamente al lector, se aprovecharía la deixis icónica como herramienta de ascenso al plano extraficcional. Insistiremos en ello más adelante, pero es importante destacar cómo las

${ }_{19}$ Cohn, D. "Metalepsis and Mise en Abyme", en Narrative, vol. 20, n. ${ }^{\circ}$ 1, enero 2012, pp. 105-106. 
características de la deixis que permite la imagen - esa mirada, terriblemente ontológica, del personaje - logran un acceso al mundo "real" irreproducible en el medio literario.

Por último, en las metalepsis intraficcionales tiene lugar una intromisión entre mundos concéntricos: un comic dentro de un comic, una novela dentro de un cómic... Asociadas en literatura a las denominadas ontológicas, este tipo de metalepsis corren el riesgo de descuidarse en los estudios transmediales ya que no implican interacción alguna con el nivel discursivo, donde toman forma las particularidades propias de cada medio. Kukkonen las soslaya al concentrar su atención en las transgresiones que revelan el contexto de producción del cómic, las que nosotros hemos tipificado como discursivas. No incurriremos aquí en ese descuido, porque dentro de Promethea abundan las metalepsis intraficcionales y además asumen un papel decisivo en la operación mágica que se invoca con su lectura.

Para poner a prueba las tesis de Kukkonen y las nuestras podemos analizar algunos ejemplos tomados de Promethea que ilustren lo comentado hasta ahora e intenten exponer la complejidad que adopta el fenómeno de la metalepsis en la historieta. Centraremos primero nuestra atención en las que afectan al plano del discurso.

En el número 16 de la serie PMT / Sophie Bangs y PMT / Barbara Shelley, en su ascensión por el Árbol de la vida, alcanzan la sefirá de Netsaj y se sumergen en un océano de sentimientos. Allí pueden contemplar acontecimientos del pasado mostrados en el interior de unas burbujas que operan como viñetas. Las dos Prometheas se ven así convertidas aparentemente en lectoras del mismo cómic que leemos nosotros desde la realidad extraficcional. Una paradoja que invita a la sospecha y a pensar en esa doble página como un ejemplo de metalepsis.

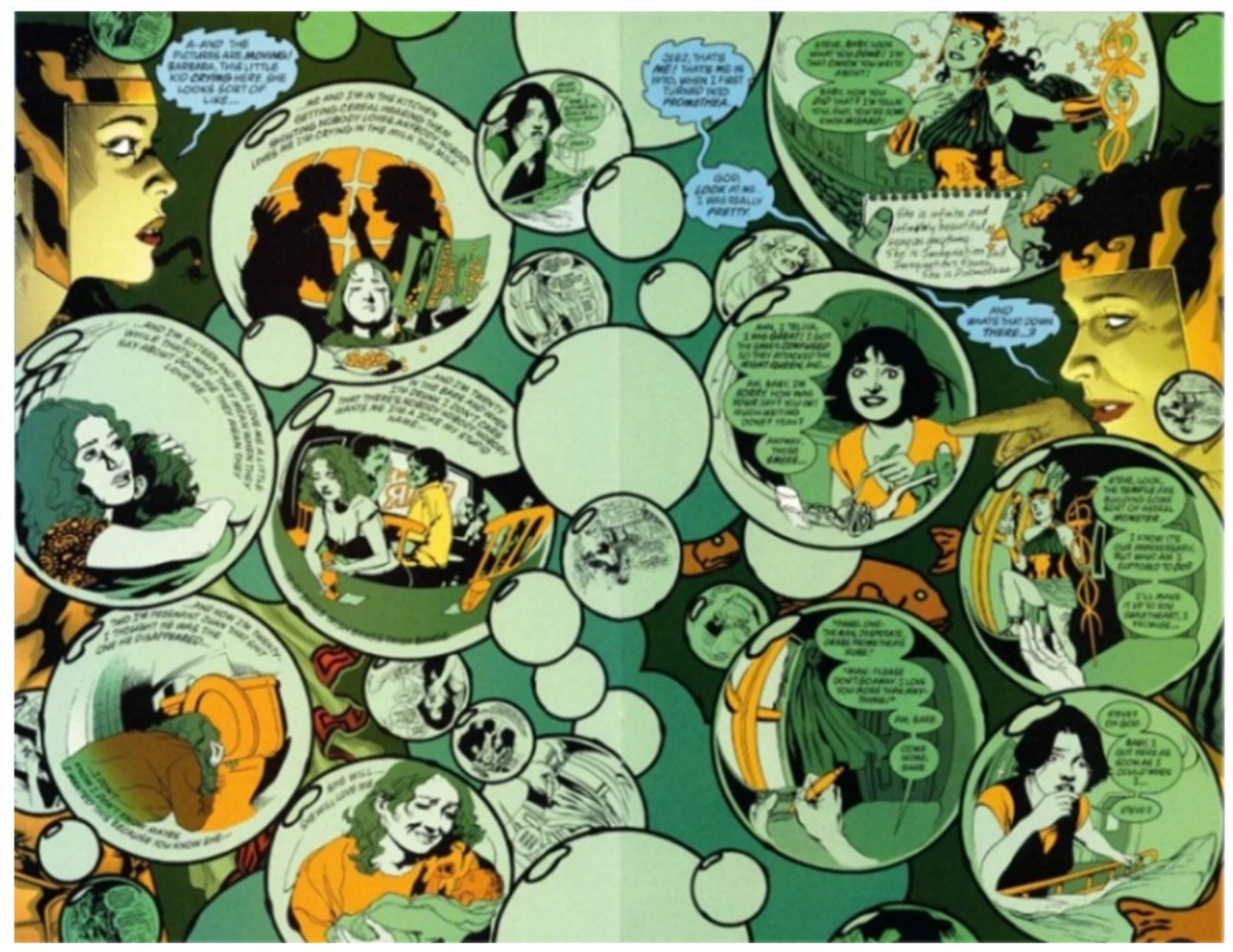

FIG. 6. Página doble 12-13 del n.o 16 de Promethea (octubre 2001). 
Sin embargo, en el plano ficcional que habitan PMT / Sophie y PMT / Barbara lo que ellas estarían contemplando, dentro de esas burbujas, se parecería más a una representación audiovisual que a un cómic. Aunque para representar esa situación no existe otra posibilidad que hacerlo con los códigos del medio, poniendo en abismo un cómic dentro de otro, en su mundo ficcional los personajes no están leyendo lo mismo que nosotros; hacen algo similar a ver la televisión, y considerar esta página como una metalepsis resulta problemático.

Pero pese a que las viñetas en forma de burbuja sirvan para metaforizar una experiencia audiovisual diferente, si consideramos el discurso en su literalidad es innegable que está teniendo lugar una metalepsis ascendente: PMT / Sophie y PMT / Barbara leen el mismo cómic que nosotros. Este ejemplo resulta mucho menos obvio para el lector que otros señalados anteriormente, ya que aquí el efecto inverosímil generado por la metalepsis se integra en la lógica narrativa del relato, convertido sutilmente en metáfora, con una naturalidad que predispone a aceptarlo sin sobresalto.

En el número 7 de la serie PMT / Bill Woolcott recorre junto a Sophie Bangs el sendero 32 del Árbol de la vida, el que une la sefirá de Maljut con Yesod y marca la frontera entre mundo material y territorio de la Imaginación. Según se adentran en ese camino, ambos personajes pasan a estar representados mediante fotografías en lugar de con dibujos y sus bocadillos de diálogo se vuelven semitransparentes.
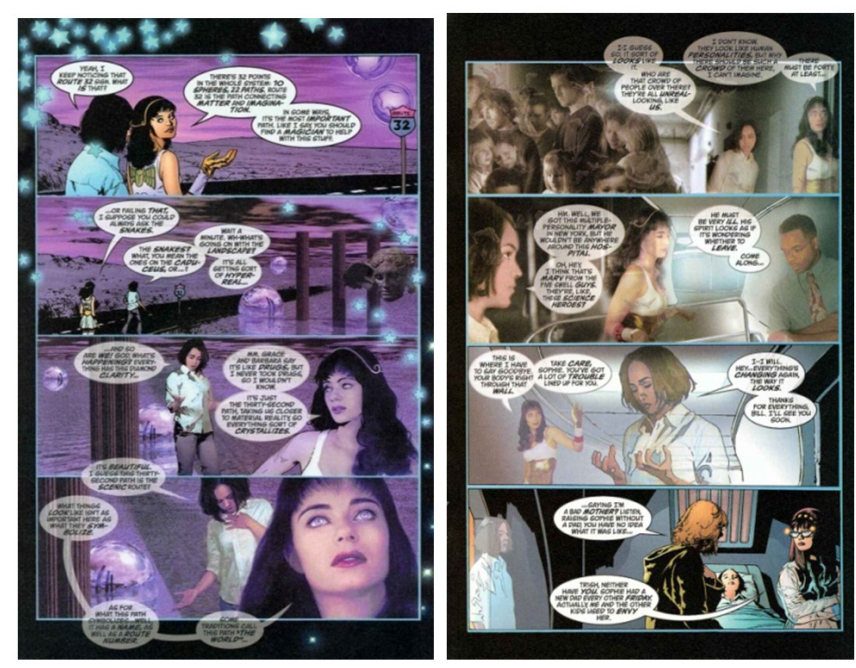

FIG. 7. Páginas 13 y 21 del n. 7 de Promethea (abril 2000).

De nuevo aquí hallamos una situación compleja que podría interpretarse o no como una metalepsis. Es cierto que el viraje hacia el realismo en la representación icónica tiene sin duda un carácter ontológico y transgresor. Pero puede leerse simplemente como una variación en el grado de mímesis asociado a la imagen; algo que pondría de manifiesto el proceso de producción del cómic aunque, aparentemente, no implicaría una interferencia entre niveles diferentes de su estructura narrativa. Sin embargo, a otra luz, en estas páginas se puede ver una metalepsis discursiva descendente. La mutación estilística que experimentan los personajes parece fruto de una injerencia directa y paradójica, ejecutada desde el mundo extraficcional por el dibujante del cómic. En esta ocasión, como en el ejemplo anterior, al utilizar el recurso como metáfora, para representar el tránsito meta- 
físico de lo material a lo imaginario, y no de modo literal, se refuerza también la ilusión asociada al pacto ficcional.

En la primera página del número 23 encontramos un caso muy parecido al que acabamos de comentar. PMT / Sophie Bangs, ya iluminada, alcanza junto a PMT / Barbara Shelley la cumbre del Árbol de la vida, la sefirá de Kéter, donde reside el aspecto más puro de la divinidad, la fecunda nada que contiene todo, la unidad absoluta en la blancura. Para representar la creación ex nibilo Moore y Williams componen una página en la que desde una viñeta circular completamente blanca emanan el resto como ondas expansivas sobre las que van surgiendo bocetos cada vez más elaborados de los personajes.

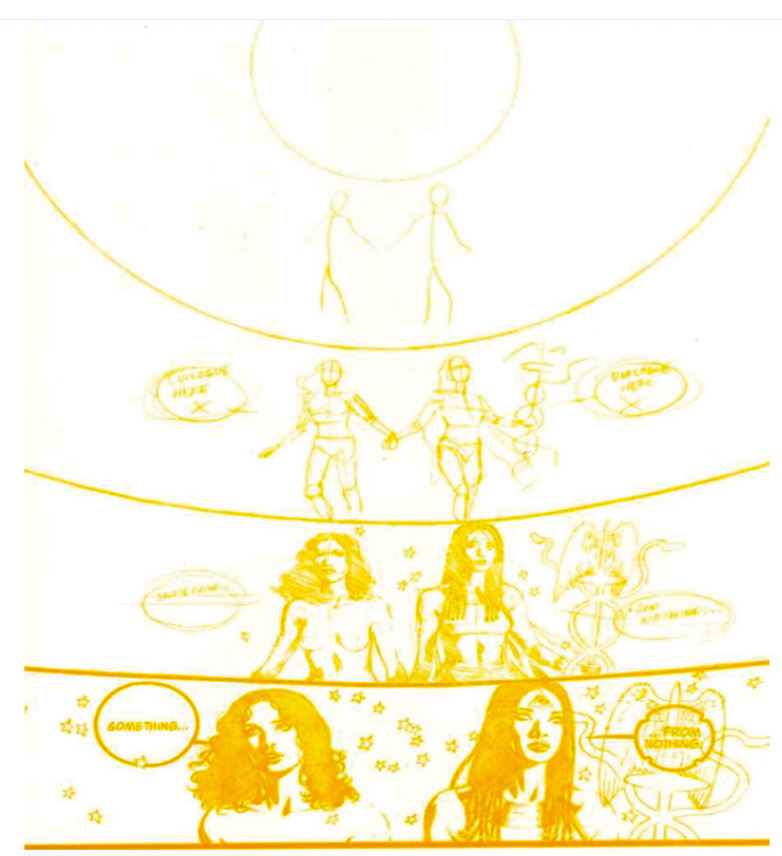

FIG. 8. Página 1 del n. ${ }^{\circ} 23$ de Promethea (diciembre 2002).

¿Podemos interpretar que esa representación del proceso de dibujo encierra una metalepsis? Sin duda se está explicitando el contexto de producción del cómic pero de nuevo es posible hacer una doble lectura del empleo de este recurso. Puede interpretarse como una elección del dibujante que no conlleva interferencia alguna en el plano de la acción, como una decisión estilística enfocada a representar de forma precisa la idea que desea trasmitir. $\mathrm{O}$ bien puede leerse como una metalepsis discursiva descendente, ya que esos bocetos pertenecen a una fase previa en la elaboración del dibujo definitivo, y convencionalmente no deberían llegar a reflejarse en la página terminada.

Francisco José Ortiz señala otro ejemplo en el que se emplean los bocetos de un modo similar en una página de los 99 ejercicios de estilo de Matt Madden, la correspondiente al titulado “¿Cómo se hace?” ${ }^{20}$ Nos enfrentamos aquí al mismo dilema, aunque quizá en este caso el conocimiento de la intención del autor, desvelada en el título del ejercicio, invitaría a decantarse desde un primer momento por la lectura metaléptica. Kukonnen refiere un caso adicional dentro del muestrario metaficticio desplegado por Grant Morrison en Animal

${ }^{20}$ Ortiz, F. J. “La Maduresa de l'autoconsciència. De Winsor McCay a Grant Morrison: variacions del metacòmic” en Ítaca. Revista de Filología. Alicante, Universidad de Alicante, 2013, p. 194. 
Man: un alienígena utiliza sus poderes para deshacerse del supervillano inmortal Hamed Ali, consiguiendo "desdibujarle" por completo. En esta ocasión resulta menos incierta la identificación de una metalepsis discursiva ascendente gracias a que el personaje del extraterrestre asume sin tapujos la función reservada al dibujante en el plano extraficcional.
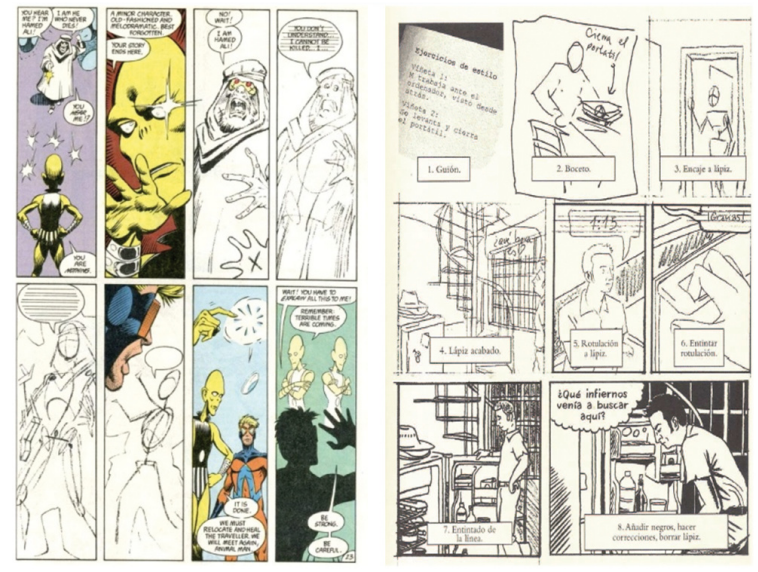

FIG. 9. Izquierda: página 23 del número 12 de Animal Man (junio 1989). Derecha: ejercicio de estilo n. ${ }^{\circ} 10:$ “Cómo se hace?” de los 99 Ejercicios de estilo de Matt Maden.

En ese mismo número 23 encontramos otra doble página en la que PMT / Sophie y PMT / Barbara se unen durante un instante a la divinidad, se fusionan con esa blancura absoluta de la que nace toda creación. De nuevo Moore y Williams emplean un recurso metaléptico para representar un motivo metafísico: las viñetas circulares que recorren los personajes se rasgan y van fundiendo a blanco hasta convertirse en su espacio negativo, en la calle que convencionalmente las separa.

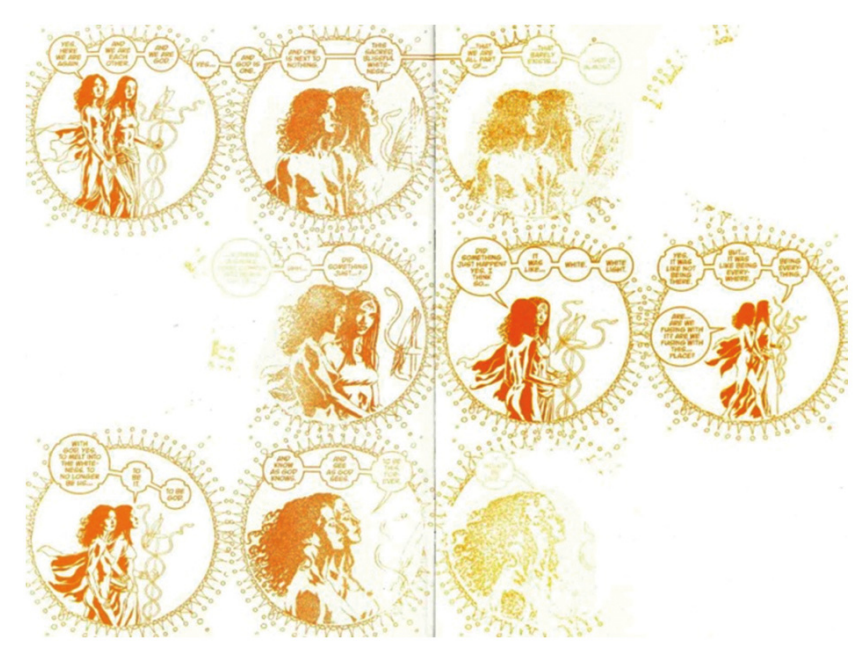

FIG. 10. Página doble 8-9 del n. ${ }^{\circ} 23$ de Promethea.

Comparar este caso de fractura - o disolución - del marco de la viñeta con el que tenía lugar en Animal Man (FIG. 3) puede iluminar el fenómeno desde otro ángulo. Una vez más, observamos cómo su empleo obedece a una intención de significar más allá del propio recurso, de metaforizar algo difícilmente representable: la unión mística. De nuevo 
aquí el uso de la metalepsis como metáfora integrada en la temática del relato enmascara en cierto modo su condición, hace difícil al lector apreciarla como tal. En cambio, cuando Animal Man atraviesa el marco de la viñeta está operando en el plano de la literalidad, la calle no significa nada ajeno a sí misma, y por eso produce en el lector un efecto de extrañamiento inmediato y más fácilmente identificable con lo metaléptico.

El empleo que se hace en Promethea de las metalepsis discursivas deja al descubierto dos dificultades críticas. La primera, implícita en la identificación de metalepsis descendentes porque, asociadas sobre todo a intervenciones de los autores que exponen las convenciones del proceso productivo de la historieta, pueden asimilarse con facilidad a meras elecciones estéticas. La segunda, porque asumiendo la perspectiva del receptor, el efecto de extrañamiento asociado a la metalepsis discursiva se suaviza al utilizarla como una metáfora más, integrada en el universo narrativo de la obra, trascendiendo su significado la literalidad del recurso.

\section{Bricomagia: desintegrando la cuarta pared para cambiar el mundo. Beta-testing la metalepsis (a nivel ficcional).}

El camino que nos ha traído hasta aquí muestra el empleo que Alan Moore y J. H. Williams hacen de la metalepsis discursiva como metáfora recurrente, eligiéndola como el recurso técnico más apto para la representación de una realidad compleja donde cohabitan superpuestos diversos estratos metafísicos. Esas metalepsis edifican el escenario donde tendrá lugar la magia, la tramoya que la hará posible. Pero los ingredientes principales para consumar el conjuro que desencadenará el apocalipsis son las metalepsis ficcionales.

El potencial mágico de la metalepsis extraficcional ascendente, su capacidad para intervenir en nuestra "realidad" al derribar la cuarta pared, es la premisa que sirve de norte geográfico a la imaginación de Alan Moore y orienta toda la serie hacia su apocalíptico final. El cómic actúa como grimorio autoejecutable, como una invocación que mediante su lectura atrae hacia nuestro plano existencial a Promethea, esa criatura que simboliza el poder creativo de la imaginación, que encarna a la Shejiná judía y a la Sophia gnóstica, y es capaz de desencadenar una iluminación global alterando la percepción de toda la humanidad. Dentro y fuera del cómic, ya lo adelantamos.

Para lograr su objetivo, esa metalepsis extraficcional ascendente que influya sobre nuestra realidad, Moore realiza una serie de ensayos preliminares a nivel intraficcional que preparan al lector para alcanzar ese momento climático y definitivo, su propia experiencia transformadora, su apocalipsis personal e intransferible. De ellos se sirve para presentar a su protagonista como personificación del recurso técnico: Promethea es una historia viva que mediante un acto de creación salta de su mundo ficcional al plano existencial inmediatamente superior; la definición misma de una metalepsis. Así sucede cuando Charlton Sennett escribe el poema épico A Faerie Romance o Margaret Taylor Case publica esa versión femenina de Little Nemo in Slumberland que titula Little Margie in Misty Magic Land; o los escritores que escriben bajo el seudónimo de Marto Neptura publican las novelas pulp protagonizadas por una Promethea que suma las virtudes de Tarzán, John Carter y Flash Gordon; cuando William Woolcott le otorga su propia cabecera en formato comic book, que continuará posteriormente Steven Shelley; o, finalmente, con los breves poemas improvisados, que escribe Sophie Bangs. Promethea adquiere su carnalidad en esos actos 
creativos inevitablemente asociados al arquetipo de lo femenino, construidos como alternativas ficcionales con forma de mujer de personajes célebres procedentes de todos los ámbitos de la cultura popular.

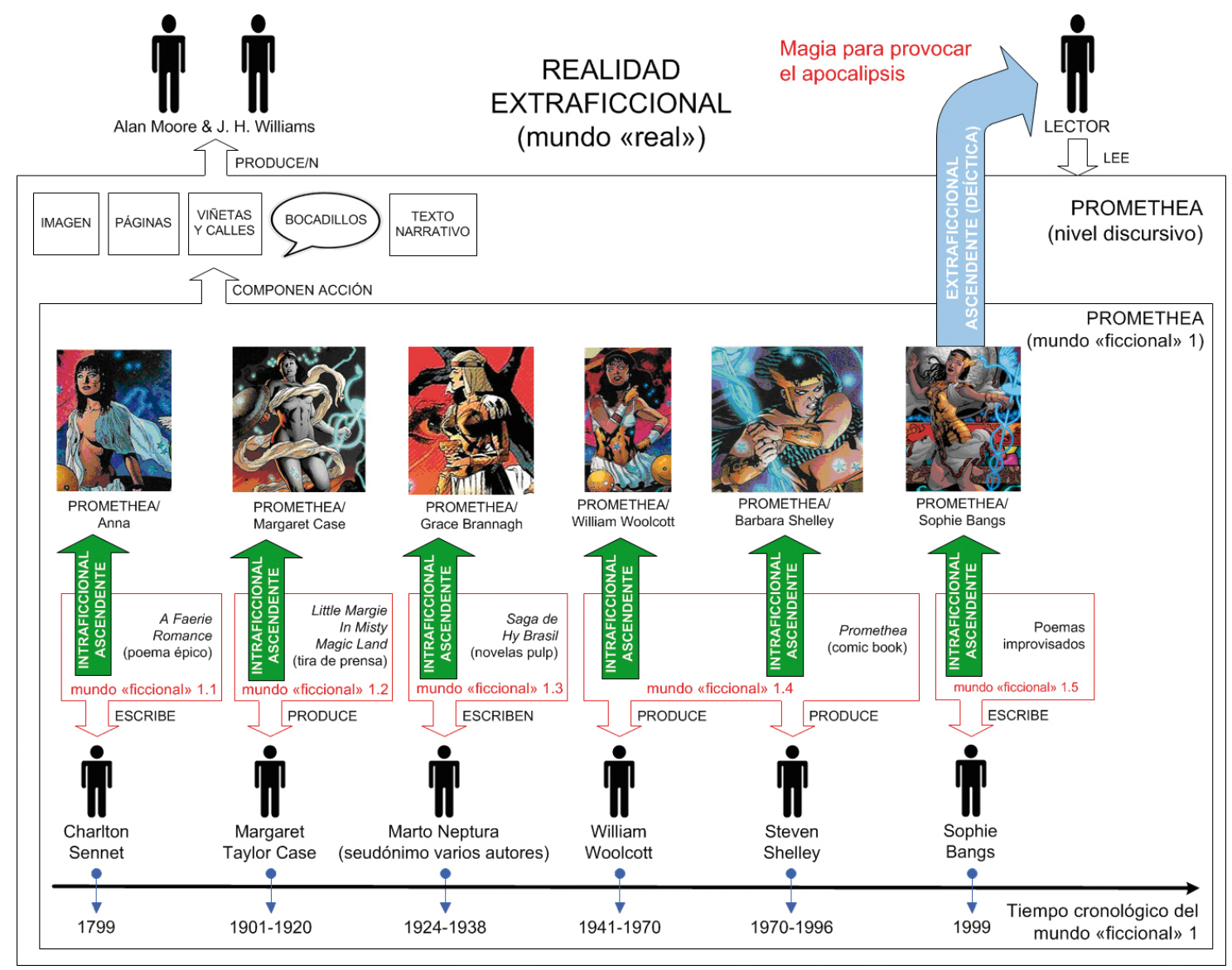

FIG. 11. Metalepsis intraficcionales para definir al personaje de Promethea.

El cómic avanza inexorable hacia la epifanía que iluminará al lector, la demolición imposible de la barrera que separa lo ficcional de lo extraficcional. Y como parte de los preparativos que requiere esa iniciación, Moore y Williams - del mismo modo que hacían con las metalepsis intraficcionales - introducen en varias ocasiones un mismo recurso, preludiando su despliegue definitivo. Antes de demoler por completo la cuarta pared calan y sondean repetidamente el espacio al otro lado del muro que separa ficción y realidad. Taladrando la viñeta a golpe deíctico, martilleando la página con las miradas de varios personajes, anticipando ese instante decisivo en que Promethea podrá ver y hablar a su lector.

Así, en el número 6 de la serie asistimos por primera vez al empleo de la metalepsis extraficcional ascendente cuando PMT / Grace Brannagh se gira hacia el lector para imprecarle por su adolescente afán voyeurístico. El sobresalto inicial queda superado al pasar la página y percatarnos de que su reprimenda está dirigida a Kenneth, el clarividente de los Cinco Magníficos, que observa el interior de la mente de Sophie mientras esta yace en la cama del hospital (FIG. 12).

Posteriormente, en su ascenso por el Árbol de las sefirot, PMT / Barbara Shelley y PMT / Sophie Bangs alcanzan la esfera de Hod y la atraviesan dejándose guiar por Hermes, 


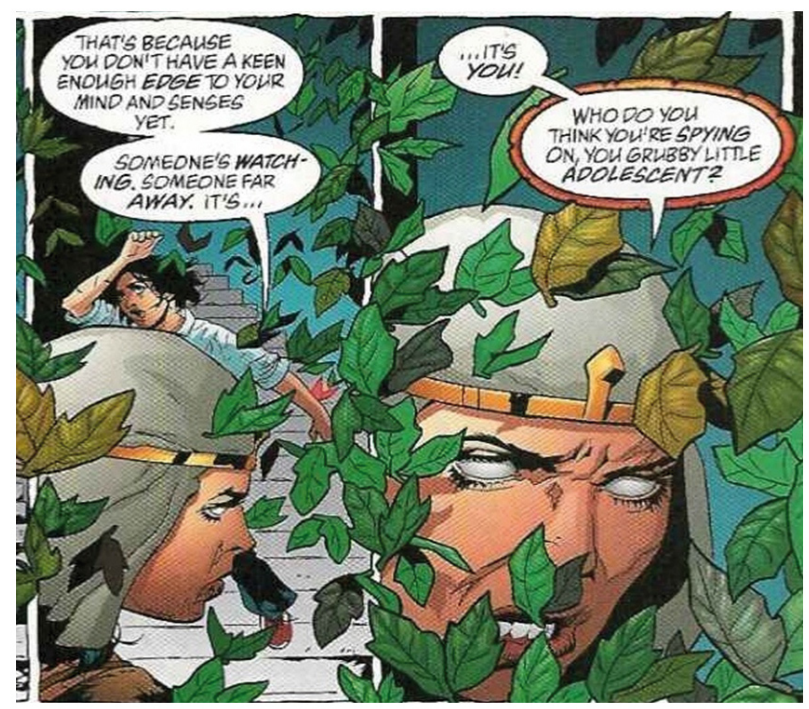

FIG. 12. Viñetas de la página 15 del n. ${ }^{\circ} 6$ de Promethea (marzo 2000).

dios del lenguaje. Tras afirmar la realidad ontológica de las ficciones, de la energía vital que alienta ciertos relatos, Hermes se gira para dirigir una mirada cómplice al lector. Con ese gesto subraya todo lo que acaba de decir, otorga una veracidad incontestable a sus palabras; porque esa deixis edifica simultáneamente los dos planos a los que hace referencia, ficción y realidad, al salir de uno y entrar en otro. Esa mirada los hace presentes, otorga veladamente a ambos un estatus existencial equivalente.
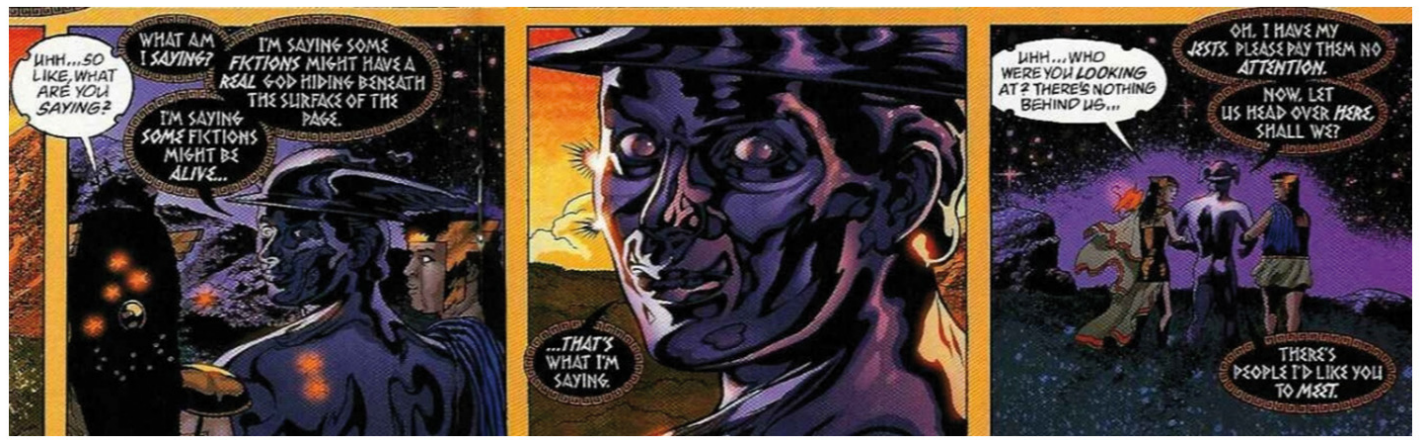

FIG. 13. Viñetas de las páginas 16-17 del n.o 15 de Promethea (agosto 2001).

Cerca de la cima de su ascenso, en la esfera de Hojmá, PMT / Sophie, iluminada y sabedora de su papel en la revelación apocalíptica, mira al lector cuando PMT / Barbara le pregunta si cree que el fin del mundo ha comenzado (FIG.14). Y con esa mirada, con ese silencio expectante, le traslada indirectamente la pregunta, le hace llegar la interpelación obligándole a reflexionar: ¿he experimentado ya la iluminación gnóstica? La respuesta es: no todavía. Promethea aún no puede vernos y hablarnos.

Esas tres miradas van proporcionando mayor consistencia existencial al mundo ficticio que despliega el cómic, equiparan su estatuto ontológico con el afuera de la página, dotándole progresivamente de mayor espesor hasta que llegue a adquirir la carnalidad suficiente para que pueda desatarse el Apocalipsis. Llegado ese momento el velo debería caer y el lector se expondría a una vivencia similar a la experimentada por los personajes 


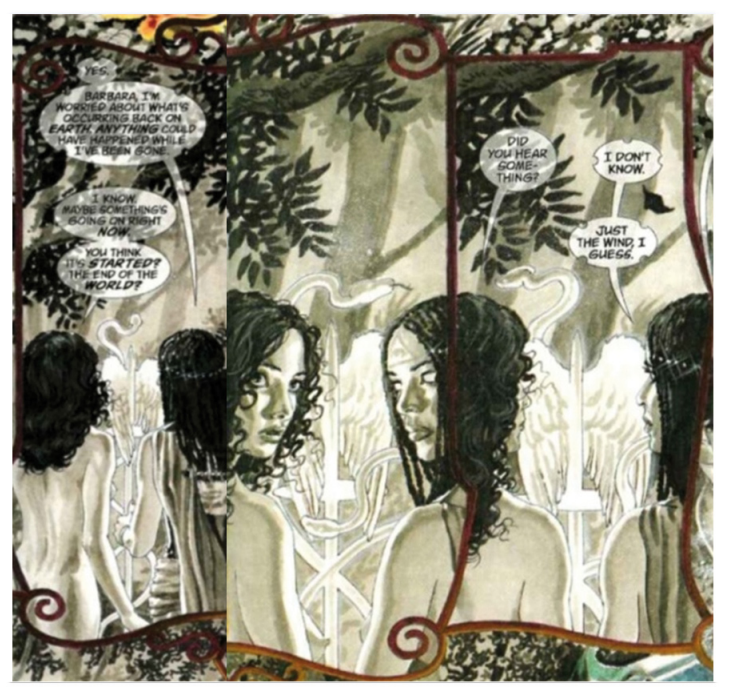

FIG. 14. Viñetas de las páginas 20-21 del n. ${ }^{\circ} 22$ de Promethea (noviembre 2002).

dentro del cómic, a la gnosis, a su misma revelación apocalíptica puesta en abismo para extender su contagio.

Y esa apertura definitiva del sendero 32 tiene lugar en el apartamento donde viven Sophie Bangs y su madre, en el que están reunidos todos los protagonistas de la serie durante ese momento climático. Su inauguración al público explosiona con un acto de magia simpática, con un gesto simbólico en un microcosmos que tiene efectos a escala macrocósmica. Trish Bangs introduce un agitador en un vaso con hielo y reproduce involuntariamente el acto de unión entre todo lo masculino y femenino, entre la varita y el cáliz. Entonces la Inmateria estalla dentro del cómic, detona un nuevo Big Bang - Sophie Bangs- que propaga su onda expansiva multicolor irradiando su poder transformador a todo lo que alcanza. Para reproducir ese efecto Moore y Williams recurren a una técnica que habían utilizado previamente, en ese primer viaje que emprende Sophie por el sendero 32 del árbol sefirótico (FIG. 7) y que ahora recorrerá la humanidad al completo. Todo lo que toca ese flujo restaurador adquiere un estilo de dibujo próximo a lo pictórico que transmite al lector un mayor grado de realismo, un efecto mimético de mayor proximidad que el entintado y coloreado tradicionales.

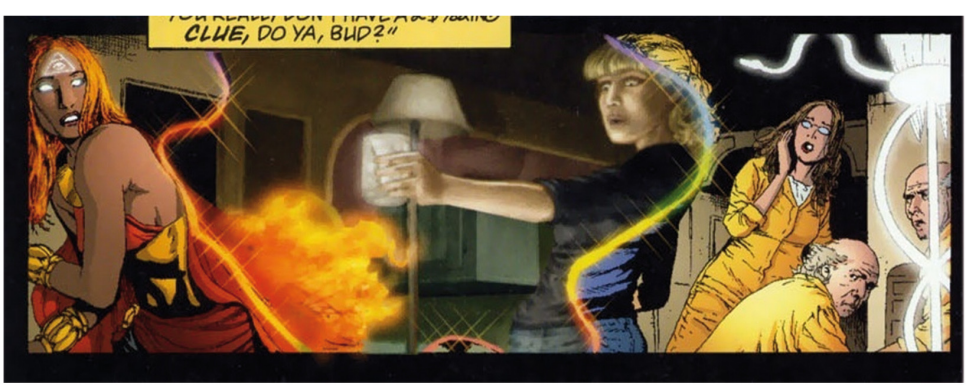

FIG. 15. Viñeta de la página 22 del n. ${ }^{\circ} 28$ de Promethea (enero 2004).

Todo está preparado para que la Promethea iluminada disponga por fin de la intimidad necesaria y pueda ver al lector y dirigirse a él sentada junto al fuego del hogar, el lugar desde el que las historias nos han hablado siempre. Y para acortar todavía más la distancia de ese contacto metaléptico, Moore y Williams, además de lanzar a Promethea hacia 
fuera, tiran del lector hacia dentro, le introducen en el cómic utilizando al personaje del Muñeco como vehículo en la doble página que se muestra a continuación.
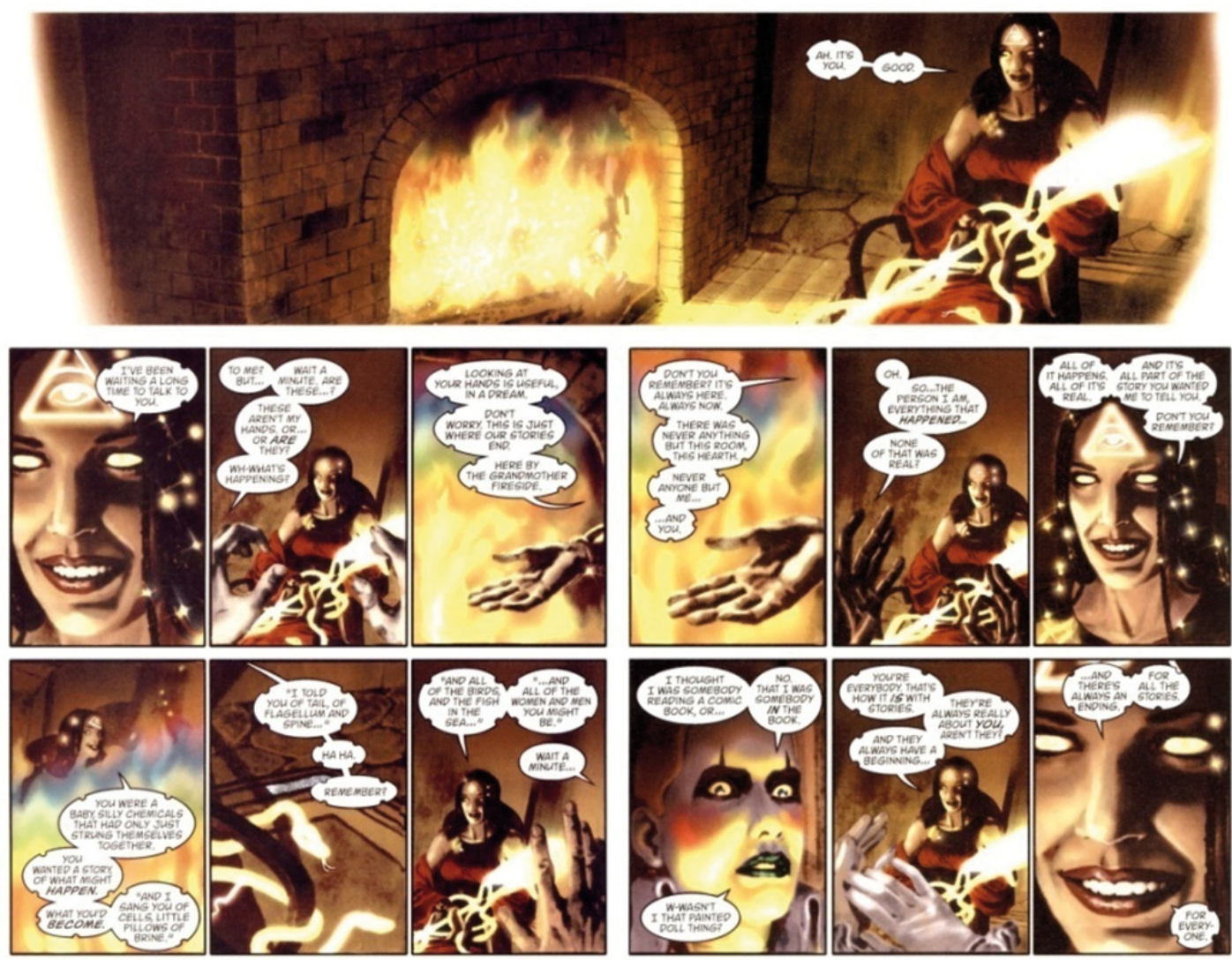

FIG. 16. Páginas 6-7 del n.o 30 de Promethea (julio 2004).

El apocalipsis no solo suprime la percepción lineal del tiempo, otra de sus consecuencias es la disolución de la identidad personal, la fusión de todas las consciencias individuales en una colectiva. En ella se reúnen las de todos los personajes del cómic y en esa totalidad se hace también espacio para que entre la del lector. Varias de las viñetas que componen esta doble página asumen la perspectiva del Muñeco, incorporando la visión de sus propias manos. Pero esas manos pertenecen a dos dueños diferentes, son simultáneamente las del Muñeco y las del lector. Esa ambigüedad, ese temblor ontológico, se subraya con su aparición en ocasiones cubiertas con guantes - Muñeco- y en otras desnudas -lector-. Y la incertidumbre identitaria, el parpadeo entre lector y personaje, se traslada también a los diálogos: "Estas no son mis manos. ¿O sí lo son?” ¿Son las manos del lector o las del muñeco? ¿Quién está hablando? ¿A quién pertenece esa visión subjetiva, al personaje o al lector? En la única viñeta donde se ve claramente el rostro del Muñeco sus palabras dispersan cualquier tipo de duda: "Creía que era alguien que estaba leyendo un cómic, o... no, era alguien dentro de ese cómic”. La respuesta de Promethea descifra el dilema: "Eres todo el mundo. Así es cómo funcionan las historias". La dificultad que conlleva incorporar a la ficción entidades procedentes del plano extraficcional se solventa así gracias a una intervención conjunta de elementos significativos: el motivo temático de la fusión en una consciencia única, el juego con la visión subjetiva de un personaje que se asimila de forma natural a la del lector, el énfasis con el juego de aparición y desaparición de los guantes y las dudas existenciales reflejadas en los diálogos del Muñeco. De este modo se ejecuta ante nuestros ojos algo difícil de presenciar: la metalepsis extraficcional descendente de un lector. 
En páginas sucesivas Promethea le sigue mirando desde el otro lado de la página, dirigiéndose directamente a él, incorporado plenamente a esa conversación global en la que participa toda la humanidad dentro del cómic. Las metalepsis se multiplican y comienza su escalada hacia el clímax. El pasadizo que se abre entre ficción y realidad se ensancha todavía un poco más cuando a través de él pasan los autores del cómic en otra página que, viñeta a viñeta, reúne un catálogo de metalepsis.

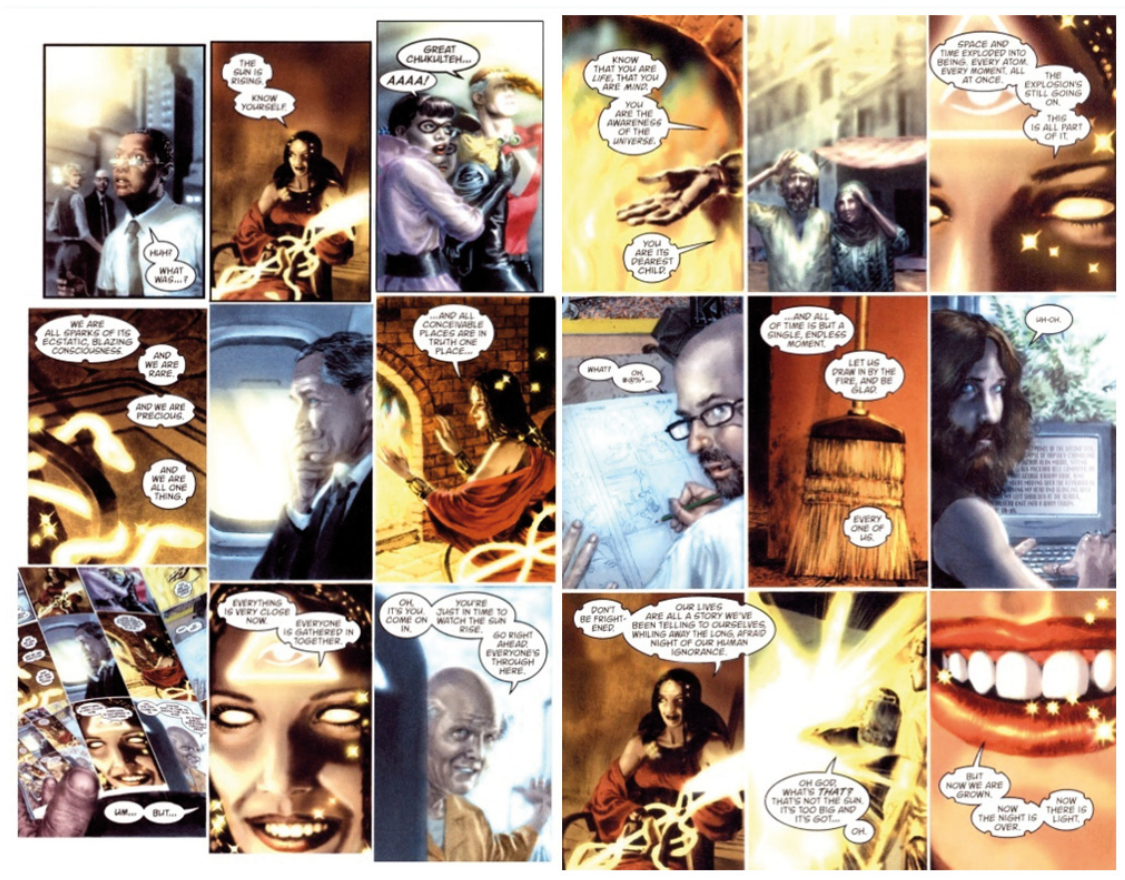

FIG. 17. Páginas 22-23 del n.o 30 de Promethea (julio 2004).

El dibujante, J. H. Williams, mientras se dibuja a sí mismo se gira para mirar más allá de la misma página que el lector lee en ese momento. Alan Moore, se da también la vuelta mientras se guioniza a sí mismo en la viñeta que el lector está leyendo. En ambos casos tiene lugar una conjunción de recursos que eleva al cubo la naturaleza paradójica de lo metaléptico al combinar:

1. Una puesta en abismo - el dibujante se dibuja en el momento de hacerlo, componiendo una puesta en abismo pura $;^{21}$ el guionista se escribe del mismo modo- que construye una metalepsis discursiva de dirección indefinible — ¿desde dónde se dibuja y se guioniza? ¿desde la acción o desde el nivel extraficcional?-.

2. Con una metalepsis extraficcional que es al mismo tiempo descendente - una representación figural de los autores se introduce en el nivel de la acción- y ascendente - esos autores ficticios miran al lector en el afuera de la página—.

Y dentro ya del cómic los autores, la convulsión arrastra con ellos de nuevo al lector. Hacia una viñeta donde se muestra la misma visión subjetiva empleada previamente pero sin

\footnotetext{
${ }^{21}$ Dorrit Cohn afirma que una puesta en abismo pura, aquella en las que un motivo aparece proyectado dentro de sí mismo en una sucesión de repeticiones infinitas, solo puede tener lugar dentro de una imagen. En la literatura este tipo de puestas en abismo pueden sugerirse mediante descripciones debido a la linealidad que impone su forma, que las condenaría a convertirse en un sumario autosimilar repetido a velocidad creciente (CoHn, D. Op. cit. p. 109).
} 


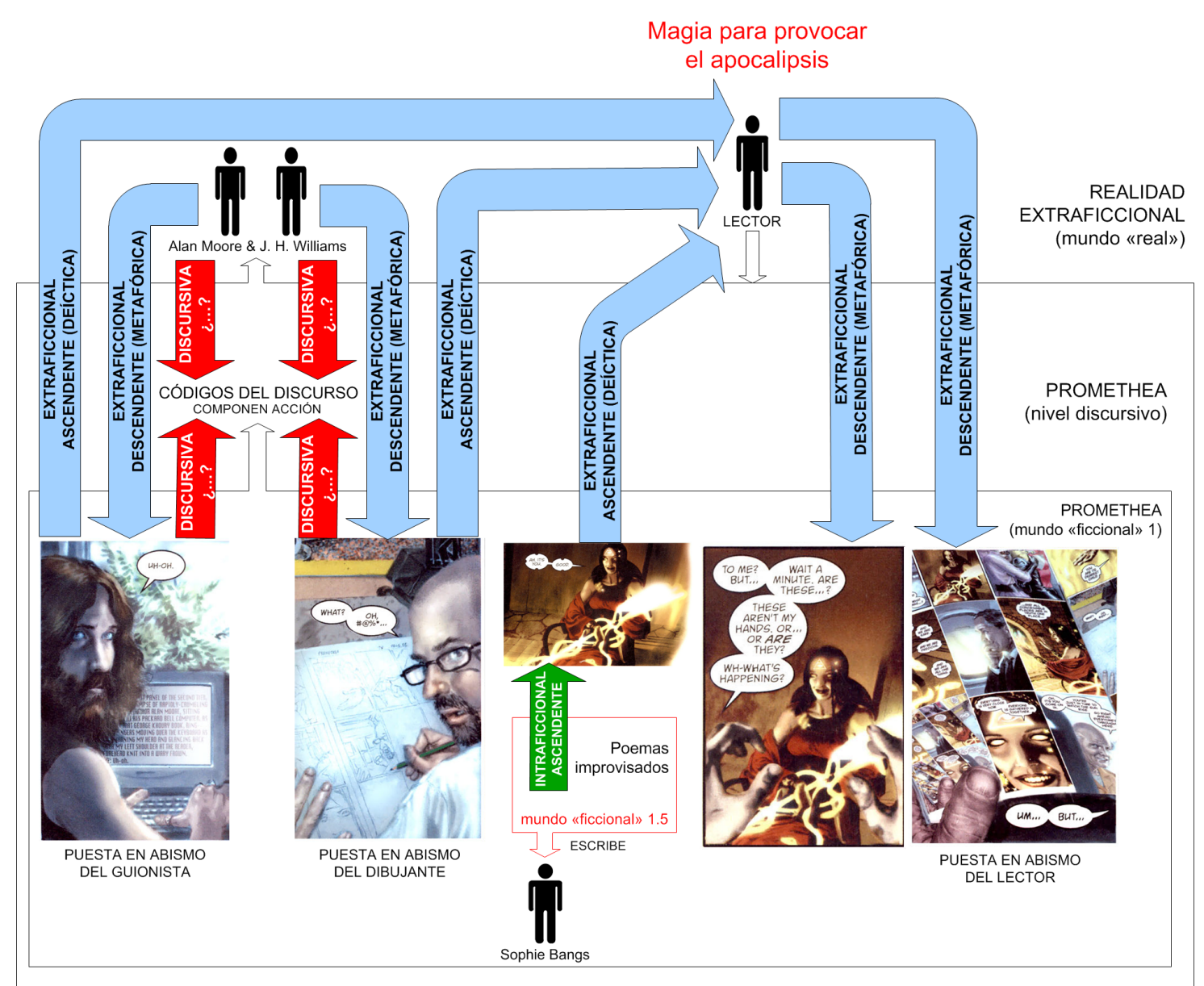

FIG. 18. Esquema de metalepsis en las páginas del n.o 30 de Promethea (julio 2004).

dejar lugar a dudas sobre su poseedor: la mano que aparece en ella sujeta el número 30 de Promethea abierto por esa misma doble página, edificando otra puesta en abismo pura. Con esa sucesión de bucles circulares se amplifica exponencialmente el temblor metaficcional. Esa cadena de tornados ontológicos colapsan realidad y ficción en un mismo espacio-tiempo donde su diferenciación se hace confusa. Gracias a las puestas en abismo se suprime el tiempo y se impone el ahora: el cómic se produce en el mismo instante en que se lee que es ese mismo momento en que Promethea desencadena la revelación gnóstica que anula la percepción temporal. La cuarta pared, golpeada simultáneamente desde su interior y su exterior, cae irremisiblemente derribada. ${ }^{22}$

Podría parecer que con esa última conversación, que ocupa gran parte del número 31 de la serie, se consuma definitivamente el Apocalipsis y la gnosis del lector; pero no es así.

\footnotetext{
${ }^{1}$ Es obligatorio notar que el hechizo para cambiar el mundo que invocan Moore y Williams tiene un destinatario explícito, habitante del mundo real, que aparece también introducido en esas páginas del número 30: George W. Bush Jr., presidente de los Estados Unidos durante la publicación de la serie. La sombra del 11-S y lo sucedido posteriormente, en esos primeros años del siglo XXI, se siente con fuerza en la resolución del cómic. Se podría proyectar una ficción paralela, una ucronía donde Bush leyera Promethea y, al sentirla dirigirse directamente a él, experimentara la iluminación gnóstica con la reverberación a nivel global que un suceso semejante provocaría. La intención de Alan Moore, al ubicarlo en el epicentro del apocalipsis, parece orientada en esa dirección. No es irrazonable, si se pretende cambiar el mundo, lanzar tu mejor hechizo contra el más poderoso líder mundial. Tampoco resulta inverosímil imaginar a Bush leyendo cómics para adolescentes.
} 
Para completar el conjuro Moore y Williams proponen que sea él mismo quien ejecute unos últimos pases mágicos, le invitan a celebrar su propio ritual de magia simpática. Algo similar a esa introducción de un agitador en un vaso que simboliza la eterna unión creadora de lo masculino y femenino y detona el fin del mundo en el cómic. Una vez completada la ceremonia podrá ver más allá de las páginas el rostro de Promethea. Con ese definitivo gesto metaléptico quedará asegurada la efectividad de la invocación. Todo aquel que desee alcanzar la iluminación y ascender por la ruta 32 hacia el plano inmaterial ha de completar estas instrucciones.

1. Adquirir el último número de la edición americana de Promethea: el 32, no podía ser otro. Si está firmado por Alan Moore y J.H.Williams y su condición es Mint o Near Mint el potencial simbólico / mágico del acto resumido en el paso 2 cobra todavía más sentido.

2. Quitarle con cuidado las grapas y desencuadernar sus páginas.

3. Extenderlas sobre una superficie amplia y lisa de varios metros cuadrados. Suponerlas un puzzle, un misterio a dilucidar, un camino que recorrer.

4. Buscar la continuidad entre unas y otras y restituir el roce de esas páginas. Completar su unión y retroceder un par de pasos.

5. Si no es posible seguir las indicaciones 1 a 4, observar durante unos minutos las siguientes imágenes que muestran el resultado del proceso.
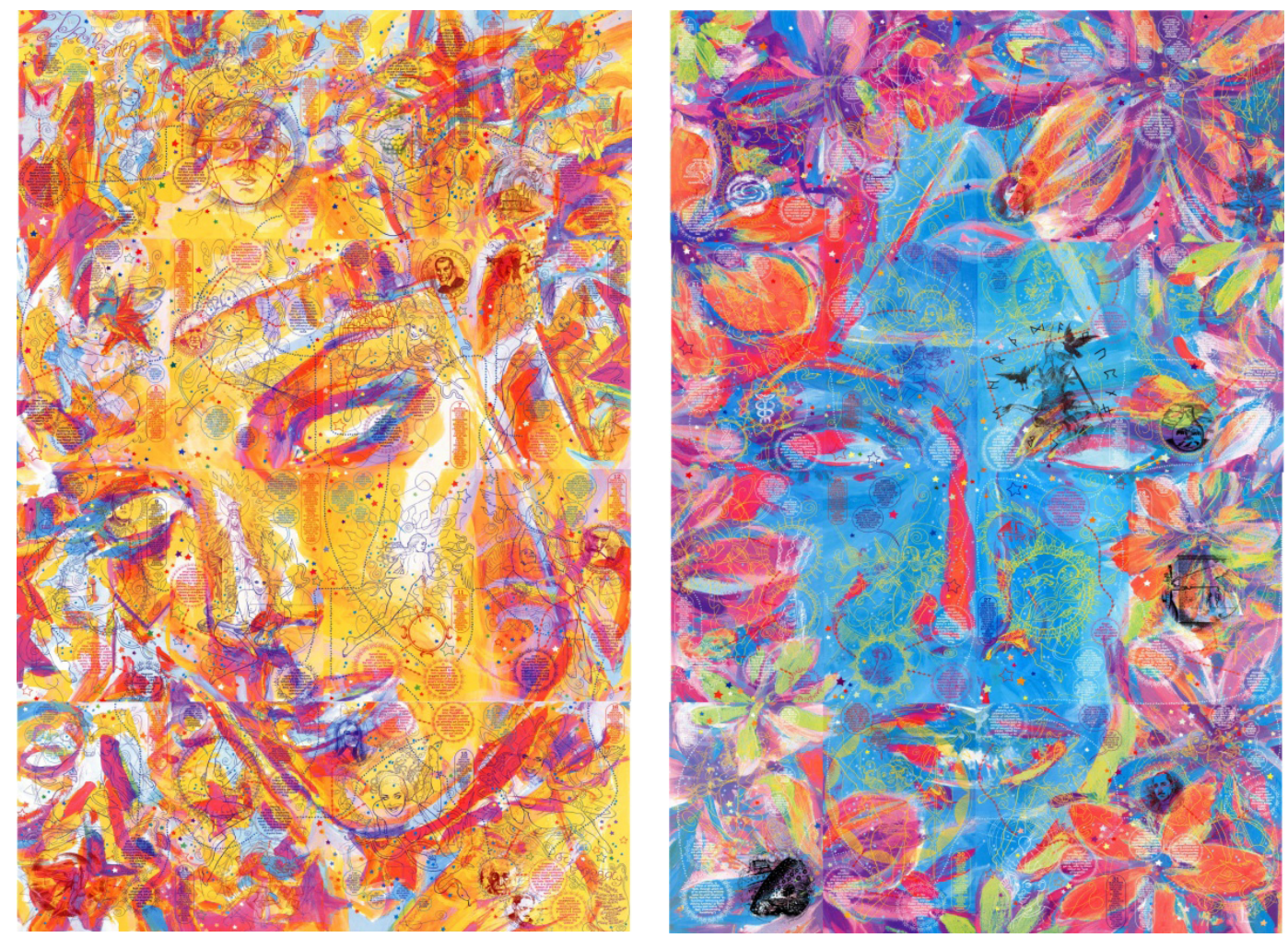

FIG. 19. El rostro de Promethea que revelan las páginas del último número de la serie. 


\section{Coda: Por un arte performativo.}

La magia no está reñida con el compromiso social; el arte y la intención de mejorar el mundo no son incompatibles. En esa frase encontramos un paralelismo sobre el que Alan Moore hace girar su poética: arte es sinónimo de magia, el artista comparte la inquietud del mago; pretende intervenir sobre el mundo real, provocar reacciones, cambios, alteraciones en el plano de la existencia donde convive con sus receptores.

En Promethea Moore y Williams nos muestran el absoluto dominio de la técnica que precisa un conjuro a gran escala. Utilizando la metalepsis discursiva como figura recurrente y dotándola de un contenido metafórico que la hace imperceptible al lector consiguen representar en un cómic la compleja topología existencial del sistema cabalístico. Jugando con las metalepsis ficcionales superponen ficción y realidad para lograr una comunión con Promethea que amplifica el impacto de sus palabras, de esa interpelación directa que lanza al lector en los últimos números de la serie. Su lectura crítica produce cierto aturdimiento según se va presenciando el despliegue de innumerables recursos en una atroz exhibición del potencial semiótico que subyace en la historieta como medio. La capacidad para expandirse hacia su afuera, para atravesar la cuarta pared, que demuestra el cómic hace palidecer a ese "querido lector" que empleaban los novelistas del siglo XVIII o a ese narrador en segunda persona, a ese "tú" presente en algunas obras modernas y posmodernas. Supone algo mucho más transgresor, tremendamente más inquietante y mucho más íntimo que el plural de modestia, ese "nosotros" que hemos empleado en este texto y supuestamente nos contiene a ti y a mí. 